\title{
Itsas ingurumenerako mikrokutsatzaile organiko hidrofobikoen presentzia eta eraginak aztertzeko estrategien taxutzea
}

\author{
(Analysis strategy design for the presence and impact of hydrophobic \\ organic microcontaminants in marine environments)
}

\author{
Mireia Irazola Duñabeitia*1,2, Oscar Posada Ureta ${ }^{1}$, Haizea Ziarrusta Intxaurtza ${ }^{1,2}$, \\ Urtzi Izagirre Aramayona ${ }^{2,3}$, Leire Mijangos Treviño ${ }^{1,2}$, \\ Maitane Olivares Zabalandicoechea ${ }^{1,2}$, Aresatz Usobiaga Epelde ${ }^{1,2}$, \\ Ailette Prieto Sobrino ${ }^{1,2}$, Olatz, Zuloaga Zubieta ${ }^{1,2}$, Iciar Martinez Galarza ${ }^{2,3}$, \\ Kepa Castro Ortiz de Pinedo ${ }^{1}$, Nestor Etxebarria Loizate ${ }^{1,2}$ \\ ${ }^{1}$ Ikerkuntza eta Berrikuntza Analitikoa (IBeA-UPV/EHU, Leioa, Euskal Herria) \\ ${ }^{2}$ Plentziako Itsas Estazioa (PiE-UPV/EHU, Plentzia, Euskal Herria) \\ ${ }^{3}$ Zelulen Biologia Ingurumen Toxikologia (BCTA-UPV/EHU, Leioa, Euskal Herria)
}

Kimika Analitikoa Saila, Euskal Herriko Unibertsitatea (UPV/EHU), P.O. Box 644, 48080, Bilbo, Euskal Herria

\begin{abstract}
LABURPENA: Lan honetan, ingurumen analisirako metodologia planteamendu berri bat proposatu da. Horretarako, kimikariek eta biologoek baldintza kontrolatuetako esposizioa egiteko elkarlanean jardun genuen. Esperimentu honetan, muskuiluak eta lagin-biltze pasiboko tresnak hainbat mikrokutsatzaile hidrofoboren eraginpean jarri ziren. Batetik, kutsatzaileen kontzentrazioak neurtu ziren, lagin-biltze puntualen zein lagin-biltze pasiboen bitartez. Bestetik, muskuiluetan kutsatzaileen kontzentrazioak neurtu ziren. Biologoek, euren aldetik, muskuiluen azterketa histopatologikoa egin zuten. Azkenik, NMR-n oinarritutako metabolomika erabili zen muskuiluek kutsatzaileen aurrean ematen zuten erantzuna aztertzeko. Lau estrategien konbinazioarekin, kausa (kokteleko mikrokutsatzaileen kontzentrazioak eta muskuiluek metatutakoa) eta eragindako efektuak (histologia azterketetan behatutakoak) hobeto uler ditzakegu. Kutsatzaileek eragiten dituzten aldaketak ulertzeko eta ondorioak azaltzeko metabolomika baliabide erabilgarria dela ondorioztatu genuen. Kutsatzaileen koktelak errute goiztiarra eragin zien muskuiluei; izan ere, NMR metabolomika erabiliz, aldaketa metaboliko nabarienak errute-egunean ikusi ziren.
\end{abstract}

HITZ GAKOAK: ingurumen analisia, muskuilua, mikrokutsatzaile hidrofoboak, NMR metabolomika, GC-MS, histologia.

\begin{abstract}
The efects of hydrophobic microcontaminants such as alkylphenols, organophosphorus compounds, organochloride pesticides, phthalates and musk fragances were studied in mussels. The proposed analytical strategy is based on the combination of passive sampling studies, bioconcentration measurements of micropollutants in mussels, environmental NMR metabolomics of two tissues (gonad, muscle) and hemolymph of mussels and histological analysis. By means of this work, it was verified the feasibility of this strategy in controlled conditions with intent to use it in future environmental studies. The micropollutants mixture was responsible of early spawning in mussels. In fact, the most significant metabolic changes were observed in the same day that spawning took place.

KEYWORDS: Environmental analysis, mussel, hydrophobic microcontaminants, NMR metabolomics, GC-MS, histology.
\end{abstract}

* Harremanetan jartzeko / Corresponding author: Mireia Irazola Duñabeitia, Kimika Analitikoa Saila, Euskal Herriko Unibertsitatea (UPV/EHU), P.0. Box 644, 48080 Bilbo, Bizkaia. Euskal Herria. - mireia.irazola@ehu.eus - https://orcid.org/00000001-8321-5434.

Nola aipatu / How to cite: Irazola Duñabeitia, Mireia; Posada Ureta, Oscar; Ziarrusta Intxaurtza, Haizea; Izagirre Aramayona Urtzi; Mijangos Treviño, Leire; Olivares Zabalandicoechea, Maitane; Usobiaga Epelde, Aresatz; Prieto Sobrino, Ailette; Zuloaga Zubieta, Olatz; Martinez Galarza, Iciar; Castro Ortiz de Pinedo, Kepa; Etxebarria Loizate, Nestor (2020). «ltsas ingurumenerako mikrokutsatzaile organiko hidrofobikoen presentzia eta eraginak aztertzeko estrategien taxutzea»; Ekaia, ale berezia 2020, 189-219. (https://doi.org/10.1387/ekaia.21057).

Jasoa: 31 uztaila, 2019; Onartua: 3 martxoa, 2020

ISSN 0214-9001 - elSSN 2444-3255 / (c) 2020 UPV/EHU

(c) (i) Obra hau Creative Commons Atribución 4.0 Internacional-en

lizentziapean dago 


\section{SARRERA}

Airea, ura, lurra eta biota bezalako ingurumen-konpartimentuetan, mota askotariko kutsatzaile organikoak metatzen dira. Kutsatzaile horiek jatorri antropogenikoa dute orokorrean: industriako prozesuak, jakien industria, farmakoak, kosmetikoak, eta abar. Hain zuzen ere, gizartearen neurri gabeko kontsumoak eta hondakinen kudeaketa desegokiak ingurumen arazo larri bat sortu dute. Kutsatzaile horiek, ingurumen-konpartimentuetan aztarna-mailan diren arren, ingurumenean, animalietan eta gizakietan eragin ditzaketen ondorioen inguruko kezka asko handitu da azken urteotan [1, 2]. Kutsatzaile organiko iraunkorrei buruzko (Persistent Organic Pollutants, POPs) Stockholmeko hitzarmena itun globala da, giza eta ingurumen-osasuna ingurumenean iraunkorrak diren eta munduan zehar hedatu, gantz-ehunetan metatu eta izakientzat zein ingurumenarentzat kaltegarriak diren kutsatzaileetatik babesteko. POP esposizioak osasun-arazo larriak eragin ditzake: minbizia, jaiotza-akatsak, ugalketa eta disfuntzio immunologikoa, gaixotasunekiko suszeptibilitatea eta nerbio-sistemako kalteak. Mundu-mailako arazo horren aurrean 2001. urtean onartu zen Stockholmeko hitzarmena, eta 2004. urtean jarri zen indarrean. Hasiera batean, Stockholmeko hitzarmenak hiru motatako 12 POPak aintzatetsi zituen (pestizidak, industriako kimikoak eta eratorriak). Denbora aurrera joan den heinean, gero eta konposatu gehiago aintzakotzat hartu dira, eta beste zenbait gainbegiratzeko zerrendan daude.

Arazoaren larritasunaren eta kezkaren erantzun gisa kutsatzaileen erregulaziorako araudiak sortu ziren Europako Batasunean, batez ere kutsatzaileen kontrolerako eta prebentziorako. Europako ur-zuzentaraua (European Water Framework Directive, WFD, 2013/39/EU) eta Itsas estrategiaren zuzentaraua (Marine Strategy Directive, MSD, 2008/56/ECC) araudi berrienek ingurumenerako kalitate estandarrak ezartzen dituzte. Azken bi hamarkadetan, kutsatzaile kimikoen azterketak kutsatzaile organiko iraunkorren (POPs) analisira mugatu dira [2-4]. POPen artean, pestizida organokloratuak, hidrokarburo polizikliko aromatikoak (PAH) eta bifenil polikloratuak (PCB) daude. WFDan ingurumenerako kalitate estandarrak betetzeko kutsatzaileen kontzentrazio-mailen mugak hainbat konpartimentutan adierazten dira. Gure gizartean, gero eta material eta konposatu berri gehiago sintetizatzen ditugu, industrian, kosmetikoetan, farmako berriak, hormonak, detergenteak, eta abar, eta ingurumenera isurtzen dira. Horren eraginez, analisirako eta erauzketarako teknikak berriak garatu behar izan ditugu gorabideko kutsatzaile organiko (Emerging Organic Compounds, EOCs) eta potentzialki arriskutsuak aztertzeko [5, 6]. EOC konposatu horien kontzentrazioak ng L ${ }^{-1}$ edo $\mu \mathrm{g} \mathrm{L}^{-1}$ mailan aurkitzen dira. Lan honetan EOC hauetako zenbait konposatu organiko hidrofobikoren eraginak aztertu dira.

(i) Alkilfenolak. Alkilfenol etoxilatoak surfaktante ez-ionikoak dira, eta detergenteetan, plastifikatzaileen ekoizpenean edota 
agente sakabanatzaile bezala asko erabiltzen dira [7-8]. Araztegietan kutsatzaile horiek degradatzearen produktuak are kutsatzaileagoak dira. Konposatu horiek disruptore endokrinoak dira; hau da, gizakien zein animalien ugalketan eragin negatiboak izaten dituzte $[9,10]$.

(ii) Konposatu organofosforatuak. Nekazaritza munduan pestizida eta intsektizida moduan oso erabiliak izan dira. Uretan agertzen duten disolbagarritasun altuak ingurumen konpartimentuetan aurkitzeko aukerak handitzen ditu. Izan ere, ingurumenean egonkorrak dira, eta efektu neurotoxikoak eragiten dituztela uste da $[11,12]$.

(iii) Konposatu organokloratuak. Hauek ere nekazaritza munduan erabiltzen diren pestizidak dira eta aspalditik ezagunak dira ingurumenean baita giza osasunean eragin ditzakeen kalteak [13]: kartzinogenesia, immunotoxikotasuna, neurotoxikotasuna, ugaltze-zikloaren gaineko eraginak, arnasketa-arazoak, eta abar [14]. POPen zerrendan azaltzen dira ingurumeneko konpartimenduetan duten eraginarengatik, metatzeko gaitasunarengatik, kate trofikoan duten biomagnikazioarengatik eta iraunkortasunarengatik [15].

(iv) Musketa poliziklikoak. Zaintza pertsonalerako produktuen ekoizpenak gorakada amaigabe bat bizi du, eta musketa poliziklikoak produktu horien ohiko osagaiak izaten dira. Zenbait ikerkuntza lanetan, musketak ingurumenean iraunkorrak, biometaketa handikoak direla eta disruptore endokrino bezala jokatzen dutela uste da $[16,17]$.

(v) Ftalatoak. Ftalatoen aplikazioak nonahi agertzen dira: industrian, plastifikatzaile moduan, kosmetikan eta abar (ftalatoen \% 87 PVCa ekoizteko). Beraz, ez da ezohikoa ftalatoen kontzentrazio altuak aurkitzea naturan. Zenbait ftalato, oktanol/ur partizio-koefiziente altua izanik, esekiduretan dauden materia partikulatuan kontzentratzen dira. Ftalatoek, sedimentuetan bizi diren organismoetan eragin kaltegarria izateaz gain, disruptore endokrino moduan ere jokatzen dute [18].

\subsection{Ingurumen-analisirako estrategia}

Ingurumen-arazoak aztertzeko eta horiei erantzuna emateko ikuspuntu holista bat erabili behar dugula defendatzen dugu lan honetan: hiru zientziak, hiru jakintza-arlok bat eginez, eta ez, inola ere ez, beste ikuspuntu sinplistago batetik. Gutxienez ikuspuntu kimikoa, biologikoa eta biokimikoa bat eginez arazoaren ulermen sakonago batera hel gaitezkeela defendatzen dugu. 


\subsubsection{Lagin-biltze pasiboa}

Lagin-biltze pasiboa monitorizazio-lanabes berritzaile bat da, bi helburu nagusi dituena: (i) denboran zeharreko kutsatzaileen kontzentrazioa neurtzea, eta (ii) zelatari-lana egitea, hau da, bioeskuragarri dagoen kontzentrazioaren erakusle izatea.

Lagin-biltze pasiboan, lagin-biltze pasiboko gailuak uretan dauden analitoak fluxu aske baten barruan jasotzen ditu. Prozesu horietan, lagin-biltze pasiboko materialaren ezaugarriek berebiziko funtzioa jokatuko dute. Metaketa zinetika-ekuazio honen bitartez azal daiteke:

$$
C_{S}(t)=C_{w} \frac{k_{1}}{k_{2}}\left(1-e^{-k_{2} t}\right),
$$

non Cs baita denbora jakin batean (t) lagin-biltze pasiborako materialak jaso duen analitoaren kontzentrazioa; $\mathrm{C}_{\mathrm{w}}$, uraren kontzentrazioa momentu horretan, eta $\mathrm{k}_{1}$ eta $\mathrm{k}_{2}$, metaketa- eta askapen-abiadura konstanteak, hurrenez hurren.

Lagin-biltze pasiboaren prozesuan, bi egoeratan lan egin daiteke. Hasieran, egoera zinetikoa dugu, eta amaieran, oreka egoera, laginketa pasiboko materiala edo fasea ase den puntua. Orekan dagoen puntuan abiadura-konstanteek bat egiten dute, eta haien zatiketa $\mathrm{K}_{\mathrm{D}}$ partizio konstante izenez ezagutzen da.

$$
C_{S}(\mathrm{t})=C_{w} K_{D}
$$

Eta jasotako masa bezala adierazi nahi baldin bada:

$$
M_{s}(\mathrm{t})=C_{w} R_{s} t
$$

Ms-k denbora jakin baten ondoren lagin-biltze pasiborako fasean dagoen analitoaren masa adierazten du, eta $\mathrm{R}_{\mathrm{s}}\left(\mathrm{L} \mathrm{day}^{-1}\right)$ lagin-biltzearen abiadura da. Azaldutakoarekin honela idatz dezakegu analitoaren xurgapena deskribatzen duen eredua:

$$
M_{s}(t)=C_{w} V_{s} K_{D}\left(1-e^{\frac{R_{s} t}{K_{D} V_{s}}}\right) .
$$

$\mathrm{V}_{\mathrm{s}}$ da laginketa pasiboko fasearen bolumena.

Lagin-biltze pasiboa egiteko, hainbat medio edo hainbat fase mota erabiltzen dira gaur egun. Lan honetan, polidimetilsiloxanozko (PDMS) hagatxo birakaria (stir-bar, SB), mintzez estalita dagoen eta gainazal xurgatzailea duen hagatxo birakaria (MESCO/Stir-bar, M-SB) eta polietersulfonazko 
(PES) tutuak erabili ziren. MESCOk dentsitate baxuko polietilenozko mintza erabiltzen du fase polimerikoa babesteko.

\subsubsection{Muskuiluak eta biokontzentrazioa}

Organismo urtarrak uraren kalitatearen berri emateko lekuko aproposak dira. Muskuiluak mundu osoan zehar dauden organismoak dira eta euren behatzaile-erabilera oso zabalduta dago munduan. Biotak berak dituen gantz-ehunei esker eta kutsatzaile hidrofobikoek gantzei dieten afinitateari esker, kutsatzaileak metatzen dira, eta haiek neurtzeko gai izaten gara. Horretarako, erauzketa-teknika eta neurketa-teknika egokiak erabili behar dira. Guk matrize solidoko fase dispertsioaren bidez egin genuen muskuiluen erauzketa, eta neurketarako, masa-espektrometro bati akoplatutako gas-kromatografia erabili genuen [20]. MSPD teknika 2000. urtetik erabiltzen da, eta haren prozedura erraza eta erabilgarria da. Izan ere, muskuiluetan hainbat kutsatzaileren erauzketan asko erabiltzen da [21-25].

\subsubsection{Metabolomika}

Metabolomikak, mintzaren, zelularen eta jariakin biologikoetako metabolitoen konposizioa neurtzeko prozedura analitiko osoa hartzen ditu bere gain. Analisi metabolomikoa teknologia omikoen parte da. Teknologia omikoak sistema biologikoen azterketan ezinbesteko baliabide bihurtu dira. Adibidez, genomikak geneak aztertzen ditu; transkriptomikak, RNA mezulariak; proteomikak, proteinak, eta metabolomikak, metabolitoak (lipidomikak metabolomikaren azpitalde bezala lipidoak aztertzen ditu, ikusi 1. irudia) [26].

Metabolitoak sistema biologikoetan diren pisu molekular baxuko $(<1.500 \mathrm{Da})$ konposatu organikoak dira. Metabolitoak sistema biologikoetako bide metabolikoetako entzimen erreakzioetako substratuak, tarteko produktuak edota produktuak izan daitezke. Bi metabolito mota bereiz daitezke: endogenoak eta exogenoak. Endogenoak sistema biologiko naturalaren parte dira: geneek adierazitako entzimen substratuak edota produktuak. Exogenoak, ordea, konposatu xenobiotikoen eraldaketa-produktuak dira.

Metabolomikaren bidez hiru helburu bete daitezke gaur egun: alde batetik, profil metabolikoa biltzea; bestetik, hatz-marka metabolikoa zehaztea eta, azkenik, bide metabolikoa argitzea.

Metabolomikako analisietan lau teknika dira nagusi: NMR espektroskopia, erresoluzio altuko masa espektrometria (HRMS), likido- eta gaskromatografiari akoplatutako masa-espektrometria (LC-MS eta GC-MS). Profil metabolikoaren determinazioak aplikazio asko ditu gaur egun farmakoen garapenean edota ingurumeneko analisietan: osasun egoeraren diagnosia, elikadura arloko ikerketak, landareen mekanismoen azterketa. 


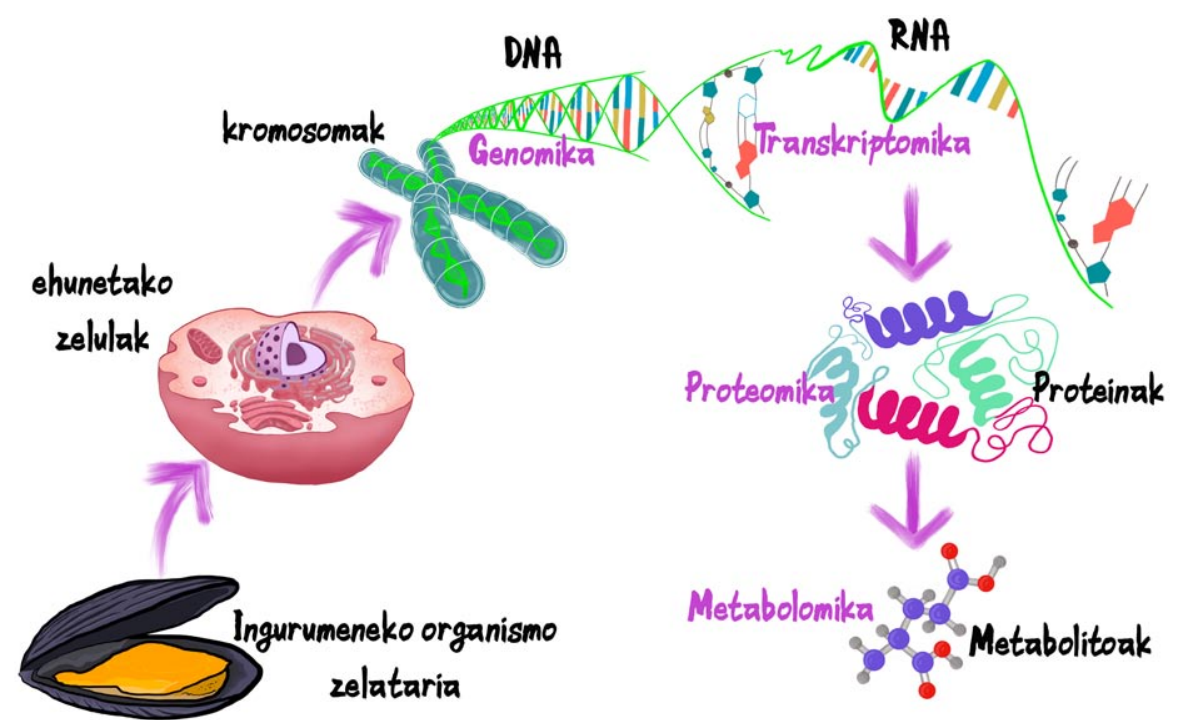

1. irudia. Teknologia omikoen eskema, dagozkion analisi-helburu eta metodoekin.

NMR neurketa nukleo atomikoaren momentu magnetikoaren eta kanpo-eremu magnetiko baten arteko erresonantzian oinarritzen da. $\mathrm{Nu}-$ kleo atomikoak eta haren desplazamendu kimikoak nukleoak inguruan dituen atomoen eragin zuzena jasaten dute; horrek, analitoaren egituraren berri ematen du. NMRko datuen interpretazioak, metabolitoen kontzentrazioaz gain, egitura kimikoaren informazioa ematen du. Espektroko gailurren azalerak eta garaierak metabolitoen kuantifikazioan erabiltzen dira.

NMRn oinarritutako metabolomikako analisi bat egiterakoan, ehunka metabolito neur ditzakegu aldi berean eta modu ez-zuzenduan (non-target). Datuak eskuratutakoan beharrezkoa da osagai askotariko analisia egitea hiru helburu nagusi betetzeko: (i) klaseen arteko bereizketa eragiten duten aldagaiak bereiztea, (ii) klase bakoitzaren profila lortzea, eta (iii) klaseen sailkapena eta taldekatzeak behatzea.

Osagai askotarikoen analisien artean karratu txiki partzialen erregresioan oinarritutako diskriminazio-analisia (PLS-DA) aukeratu da. PLS-DA gainbegiratutako teknika kimiometrikoa da. PLS erregresio-teknikak X datu-matrizea Y erantzun-matrizearekin erlazionatzen du. PLS-DA, ordea, PLS erregresio teknikaren alternatiba bat da. PLS-Dan, osagai nagusien analisian (PCAren) gertatzen den modu bertsuan, datu-matrize originala jatorrizko aldagaien konbinazio linealak diren aldagai latenteekin azaltzen da 
(PCak edo LVak). PLS-DA PLS erregresio bat da, baina erantzuna aldagai kategorikoa da, lagin bakoitzaren klasea, guk aurrez adierazi dioguna. Ondorioz, neurtutako aldagaietatik lortuko diren PLSko osagaiek bi konpromiso bete behar dituzte: erantzunak (klaseak) iragartzeko gai izan behar dute, eta klase bakoitzeko laginen aldagai neurtu guztiak azaltzeko gai izan behar dute. Datu-matrizearen joera eta multzokatzeak aztertzeko, sortutako ereduko aldagai latenteen proiekzioak aztertzen dira (scores delakoak). Eta aldagaiek laginen banaketa horretan duten eragina edo pisua aztertzeko, loadings delakoak aztertzen dira.

Eredu sinplifikatuago bat lortzeko asmoz, OPLS-DA erabiltzen da; hau da, seinaleen zuzenketa ortogonala (orthogonal signal correction, OSC) aplikatzen da PLS-DA ereduaren eraikuntzan. Azken finean, OSC zuzenketan erantzunak edo klaseak azaltzeko balio ez duten aldagaiak baztertzen ditu eredua eraikitzean. OPLS-DA asko erabiltzen da NMR metabolomikan, adibidez adina, sexua, dieta eta gisako faktoreen eragina murrizteko.

PLS-DA analisietatik aldagai garrantzitsuenak (VIP delakoak. Variables Importance on Partial Least Squares (PLS) projections) eskuratzen dira. Izan ere, analisi horietako aldagai garrantzitsuenen proiekzioak dira. VIP balioak PLSko ereduan aldagaiek duten pisuaren eta azaltzen duten bariantzaren adierazpena dira. VIPak aztertzeko orduan, 1 baino balio altuagoa duten balioak hartzen dira kontuan.

Behin informazio hori jasota, webgune eta artikuluetako seinaleen desplazamenduetan oinarrituta, gure aldagaien identifikazioa egiten dugu. Behin metabolitoak identifikatu direnean, aztertzen da zein bide metaboliko dauden aldatuta. Jasotako informazioarekin gaixotasunen diagnosia, toxikologia-azterketa, nutrizio-egoera eta estresen efektuen eraginak ulertzeko gai izan gaitezke.

\subsubsection{Histologia}

Muskuiluak organismo zelatari moduan erabiltzen dira itsasoko kutsadura monitorizatzeko [27]. Baina, batzuetan, monitorizazio horietatik lortutako datu biologikoak eta kimikoak interpretatzea zaila izaten da; batez ere, kontrolpean ez dauden aldagai kopurua oso handia delako. Tenperaturak, gazitasunak, janariaren eskuragarritasunak, urtaroak, gonaden garapenak eta abarrek eragin zuzena dute faktore horiek guztiek neurtutako parametroen erantzunean [28]. Nahasgarriak izan daitezkeen faktoreak ezagutzea eta emaitzen interpretaziorako irizpide sendoak izatea erabakigarria da kutsaduraren eraginak identifikatu ahal izateko.

Ahalik eta faktore gehien kontrolpean izateko, laborategiko baldintza kontrolatuetan egindako esperimentua egin genuen, kutsatzaileen kokte- 
laren eraginak ulertu ahal izateko. Ingurumeneko hainbat kutsatzailek (hala nola metalek, hidrokarburo aromatikoek, konposatu kloratuek, alkilfenolek, olioak, petrolioak, eta gure itsaso eta itsasbazterretan aurki ditzakegun haiek) muskuiluetan gaixotasunak eragiten dituzte [29]. Eraginaren garrantzia ehunen kalteberatasunaren mendekoa izango da, baina baita kutsatzailearen naturaren eta kontzentrazioaren araberakoa ere. Alterazio biokimikoak zelulen prozesuetan eta funtzioetan izaten dute eragina, eta denborarekin aldaketa fisiologiko eta morfologikoak azaltzen dituzte. Aldaketa fisiologiko eta morfologikoek gaixotasun jakin batzuk identifikatzeko balio dute. Beraz, aldaketa histopatologikoen kausak aldaketa metabolikoetan oinarritzen dira. Hanturako kalteak eta erantzun hiperplastikoak adibidez, organismoaren osasun eskasaren adierazgarri dira.

\section{HELBURUAK}

Oraindik ez dago ingurumen-monitorizaziorako estrategia bateraturik, eta jakintza arlo bakoitzean, bakoitzak beren ohiko analisiak egiten jarraitzen du. Guk, lan honetan, baldintza kontrolatuetan egindako esperimentuan, biologoen eta kimikoen elkarlana proposatzen dugu monitorizazio estrategia gisa. Estrategia horien erabilera frogatu nahi izan dugu lan honetan. Lau zatitan banatzen da gure estrategia:

(i) Lagin-biltze pasiboa eta uraren analisi puntualak.

(ii) Muskuiluak organismo zelatari moduan biokontzentrazioaren neurketarako.

(iii) Erresonantzia magnetiko nuklearrean oinarritutako metabolomikako analisiak muskuiluen hemolinfan, oinetan eta gonadetan.

(iv) Histologiako analisiak.

\section{MATERIALAK ETA METODOAK}

\subsection{Kontrolatutako baldintzetan egindako esperimentuak}

Esperimentuak Euskal Herriko Unibertsitateko Plentziako itsas estazioan (PiE, UPV/EHU) egin ziren baldintza kontrolatuetan. PiEren abantaila nagusietako bat hau da: iragazitako itsas ur naturalaren emari jarraitua dugula da.

Bi esperimentu mota planteatu ziren. Lehen esperimentuan, bi egunik behin ur dopatuaren berritzea egin zen $\left(10,100\right.$ eta $1000 \mathrm{ng} \mathrm{L}^{-1}$-ko kutsatzaile hidrofoboen koktela erabiliz), eta bigarren motako esperimentuan, kutsatzaile hidrofoboen koktelaren fluxu-emari konstantean lan egin ge- 
nuen. Fluxu-emari konstantean bi esperimentu egin genituen: batetik, kutsatzaile-kontzentrazio altua (100 $\left.\mathrm{ng} \mathrm{L}^{-1}\right)$ eta nahaste zabala erabili genituen, eta bestetik, kutsatzaile-maila baxua $\left(20 \mathrm{ng} \mathrm{L}^{-1}\right)$ eta nahaste sinplea erabili genituen.

\section{(i) Muskuiluen bilketa eta aklimatazioa}

Muskuiluak (Mytilus galloprovincialis) Mundakako itsasertzean batu ziren. Laginketa-puntua Bizkaiko kostaldeko erreferentziako puntu «garbia» da [30]. Laginak 2014ko otsailean eskuz jaso ziren. Batutako muskuiluak, luzeraz, 3,5-4,5 cm tartekoak ziren, eta adin-tarte bertsua zuten [31].

Aklimatazioa eta purga $1 \mathrm{~m}^{3}$-ko tanke batean egin zen, eta lehenengo 48 h-etan ez zitzaien janik eman. Denbora-tarte hori pasatu ostean, jan komertziala (Coraliquid, SERA) eman zitzaien astebeteko aklimatazioan.

(ii) 1. esperimentua: bi egunik behin aldatutako ur dopatua

Esperimentu horretan lau talde izan genituen: kontrol-taldea, kontzentrazio baxueneko taldea (10 $\left.\mathrm{ng} \mathrm{L}^{-1}, \mathrm{~L}\right)$, tarteko kontzentraziokoa (100 ng L $\left.{ }^{-1}, \mathrm{ME}\right)$ eta kontzentrazio altuenekoa (1.000 $\left.\mathrm{ng} \mathrm{L}^{-1}, \mathrm{H}\right)$. Tanke bakoitzean $30 \mathrm{~L}$ ur, 36 muskuilu eta airea etengabe pasarazten zen.

Ura bi egunik behin aldatzen zen, eta zegokion kutsatzaile-nahastea gehitzen zen. 14. egunean jaso ziren metabolomikarako laginak (hemolinfa bakarrik). Metabolomikako analisietarako talde bakoitzeko 5-10 muskuilu erabili genituen esperimentu guztietan.

Esperimentuan erabili zen kutsatzaile-koktela: (i) alkilfenolak -4-tertoktilfenola (4tOP), 4- $n$-nonilfenola (4nOP) - (ii) konposatu organofosforatua - klorpirifos (Clorp), Klorfenbinfos (Clor) -, (iii) konposatu organokloratuak -alfa-hexakloroziklohexanoa $(\alpha-\mathrm{HCH}), \beta-\mathrm{HCH}, \gamma-\mathrm{HCH}$, $\delta$-HCH, 2,4'-dikloro difenil dikloroetanoa (2,4'-DDD), 4,4'- DDD, 4,4'dikloro difenil dikloroetilenoa (4,4'-DDE), 2,4'- dikloro difenil trikloroetanoa (2,4'-DDT), 4,4'-DDT, Triklosan - (iv) musketa poliziklikoak - galaxolidea (HHCB), tonalidea (AHTN), (v) Ftalatoak: butilbenzilftalatoa (BBP), Di(2-etilhexil)ftalatoa (DOP) - .

Esperimentuko behaketa garrantzitsuena: 13 . egunean, $1.000 \mathrm{ng} \mathrm{L}^{-1}$ eko kutsatzaileen nahasteko tankeko muskuilu denen errutea gertatu zen (kontrolean ez). 
(iii) 2. esperimentua: $100 \mathrm{ng} \mathrm{L}^{-1}$ kutsatzaile hidrofoboren koktelaren fluxuemari konstantean

2. irudian ikus dezakegun moduan, hiru tanke erabili ziren esperimentuan: (1) laginketa pasiborakoa, 50 L-koa; (2) ur kutsatutan muskuiluak jartzekoa, (1) tankeari konektatuta zegoena, 65 L-koa eta (3) kontrolerako muskuiluena, ur emari garbi independenteduna, 65 L-koa.

Muskuiluak $160 \mathrm{ko}$ talde bitan banatu ziren, kontrolak eta kutsatutakoak, eta dentsitate altuko polietilenozko 65 L-ko tanketan sartu ziren. Kutsatzaile-nahastea altzairu herdoilgaitzezko tankera gehitzen zen lehenbizi. Bertan, laginketa pasiborako karrusela jarri zen. $5 \mathrm{~L} \mathrm{~h}^{-1}$-eko ur-emari kontrolatua erabili zen (ponpekin kontrolatua), ura berritzeko eta kutsatzaileak 100 ng L-1-eko kontzentrazioan mantentzeko (1) eta (2) tankeetan.

Esperimentuan erabili zen kutsatzaile-koktela: (i) alkilfenolak $-4 \mathrm{tOP}$, 4nOP-; (ii) konposatu organofosforatuak - Clorp, Clor-; (iii) konposatu organokloratuak - $\alpha$-HCH, $\beta-\mathrm{HCH}, \gamma-\mathrm{HCH}, \delta$-HCH, 2,4'-DDD, 4,4'DDD, 4,4'-DDE, 2,4'-DDT, 4,4'-DDT, Triklosana-; (iv) musketa poliziklikoak - HHCB, AHTN - ; (v) ftalatoak - BBP, DOP-.

Esperimentuko behaketa garrantzitsuena. Esperimentu honetan, 0 , 3., 5., 8., 10., 12. eta 14. egunetan laginak jasotzeko asmoa genuen, baina esperimentua hasi zen egun berean muskuiluen errute orokorra gertatu zen, eta 5 egunen buruan muskuilu denak hil ziren (kontrolean ez). Badirudi fluxu jarraituak eta kutsatzaileen kontzentrazioa konstante ziurtatzeak eragin zuzena duela esposizioan eta baita ondorioetan ere.

(iv) 3. esperimentua: $20 \mathrm{ng} \mathrm{L}^{-1}$ kutsatzaile hidrofoboren koktelaren fluxuemari konstantean

2. esperimentuko diseinu bera erabili zen 3. esperimentu honetan. Kasu honetan, ordea, kutsatzaile-nahastearen kontzentrazioa bost aldiz baxuagoa izan zen: $20 \mathrm{ng} \mathrm{L}^{-1}$. Gainera, kutsatzaile-nahaste sinpleagoa erabili zen koktelean.

Esperimentuan erabili zen kutsatzaile-koktela: (i) alkilfenolak, 4tOP; (ii) konposatu organofosforatuak, Clorp; (iii) konposatu organokloratuak - $\alpha$-HCH, 2,4-DDD, 4,4'-DDD, 4,4'-DDE, Triklosana-; (iv) musketa poliziklikoak - HHCB, AHTN - ; (v) ftalatoak - BBP, DOP-.

Esperimentuko behaketa garrantzitsuena: 3. egunean errutea hasi zen (kontrolean ez). 

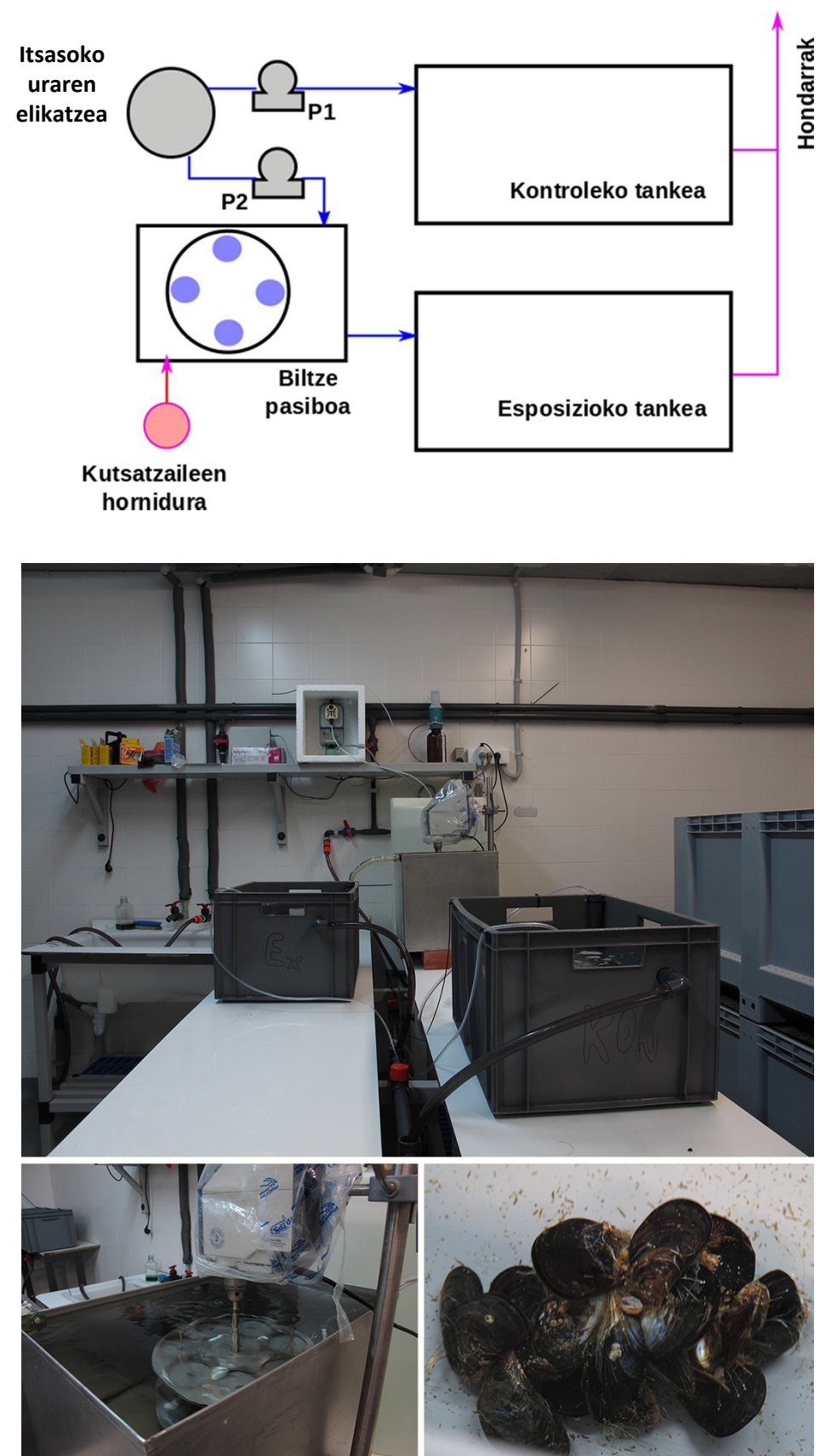

2. irudia. 2. esperimentuaren eskema eta diseinua, laginketa pasiboko karrusela eta muskuiluak. 


\subsection{Lagin-biltze pasiboa eta laginketa puntualak}

Lagin-biltze pasiboari dagokion metodologia lantaldekook argitaratua dugun artikuluan aurki daiteke [32]. 3. irudian laburbildu ditugu metodologia horri dagozkion pausorik garrantzitsuenak. Lagin-biltze pasiboko hiru hurbilketa erabili ziren: SB, M-SB, MESCO eta PES tutuak. Hagatxo birakarien kasuan, zuzenean neurtu ziren Gerstelean desortzio termikoan (TD) oinarritutako erauzketari esker; PESak, ordea, kimikoki erauzi eta bolumen handiko GC-MS bidez neurtu ziren.

Lagin-biltze puntualean (spot sampling), SB hagatxo birakariekin egin zen erauzketa laborategian, eta hori ere TD-GC-MS bitartez neurtu zen zuzenean.

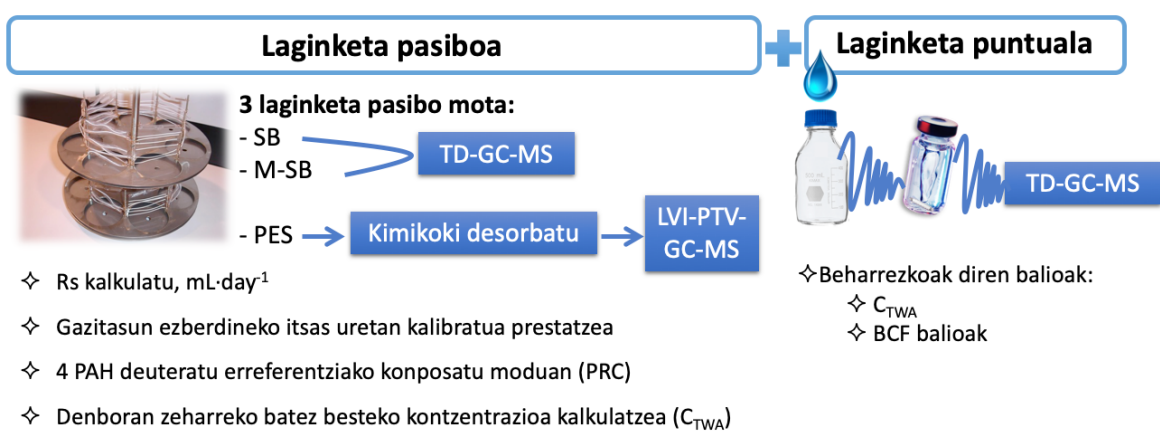

3. irudia. Lagin-biltze pasiboko eta lagin-biltze puntualeko prozeduraren eskema.

\subsection{Muskuiluak eta biokontzentrazioak}

Muskuiluak minutuero $30 \mathrm{~mL}$ ur iragazteko gai dira [33] jakiak eskuratzeko, eta ondorioz, ingurumeneko kutsatzaileak metatzen dituzte. Hori horrela izanik, muskuiluen biokontzentrazioa kalkulatzeko, MSPD erauzketan oinarritutako eta gure lantaldean optimizatutako metodoa erabili genuen (ikusi 4. irudia) [22]. Biokontzentrazio-faktorea (BCF), organismo batek ingurumenetik kutsatzaile jakin bat metatzeko duen gaitasuna da. 


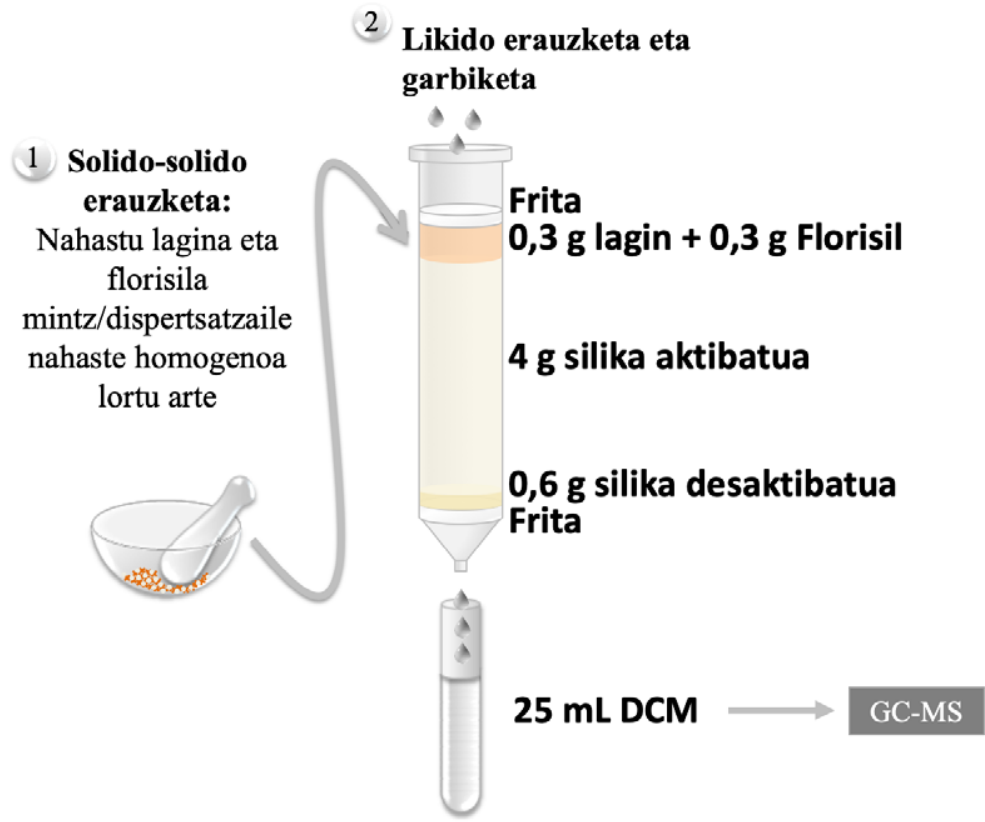

4. irudia. Muskuiluen biokontzentrazioa neurtzeko prozeduraren eskema, MSPD bidezko erauzketa.

\subsection{NMR metabolomika}

Metabolomikako analisietan laginaren tratamendua pauso kritikoa da. Batez ere, laginaren osotasuna bermatzeko kate-hotza ez apurtzea berebizikoa da.

Lan horretan muskuiluen jariakina eta 2 ehun aztertu ziren: hemolinfa, oina eta gonada. Hemolinfa, muskuilua bizi zegoelarik, muskulutik xiringa batekin jaso zen (150 $\mu \mathrm{L}-450 \mu \mathrm{L}$ inguru jasotzeko gai izan ginen). Bestalde, 25-100 mg masa tarteko oin eta gonadak batu genituen eskalpeloaren eta artazien laguntzaz. Ahal bezain lasterren nitrogeno likidotan bat-batean izoztu genituen, eta ondoren, $-80{ }^{\circ} \mathrm{C}$-an gorde ziren laginak.

Ehunen metabolito hidrofiliko eta hidrofoboen erauzketa konbinatua egin zen, kloroformo-, metanol- eta MilliQ ur-nahastea eta Precellys-cryolys homogeneizatzailea erabiliz. Prozeduratik eskuratutako fase polarrak (eta hemolinfak) liofilizatu egin ziren, eta erauziak neurketa-egunera arte $-80{ }^{\circ} \mathrm{C}$-an gorde ziren. Lagin-tratamendua, mundu-mailan NMRko ingurumen metabolomikan erreferente den Mark Viant ikertzailearen taldekoek optimizatutako lanean oinarritu da $[34,35]$. 
Liofilizatutako erauziak ur deuteratutan prestatutako $\mathrm{pH} 7,4 \mathrm{ko}$ tanpoiko $550 \mu \mathrm{L}-\tan$ berreratu ziren. NMRko neurketak SGIkerreko (UPV/ EHU)ko $500 \mathrm{MHz}$ Bruker AVANCE 500 espektrometroan egin ziren. Behin NMRko datuak eskuratuta, espektroak Matlab-era inportatu ziren $R B N M R$ funtzioa erabiliz, eta bi analisi mota egin ziren: PCA eta OPLS-DA. PCA analisia datuen distribuzio eta ezabatu beharreko lagin susmagarriak topatzeko erabili zen. OPLS-DA erabiltzeak, ordea, taldeen arteko bereizmena handitzea eta VIPak eskuratzea du helburu. Modu horretan lortutako informazioarekin, aldagai garrantzitsuenen seinaleen identifikazioa egin zen. Behin seinale (desplazamendu kimikoak) bereizgarriak zeintzuk diren ezagututa, metabolitoen seinaleen esleipena egiteko sarean aurkitutako data-baseetan [36-38] eta artikulu zientifikoetan oinarritu ginen $[39-43,43]$.

\subsection{Muskuiluen analisi histopatologikoa}

Biologoek egindako analisi histopatologikoaren bidez lortutako emaitzarik adierazgarrienak jaso ziren. Horretarako, laginak finkatu eta parafinatan prestatu ziren. Ondoren, $5 \mu \mathrm{m}$-ko ebakiak egin ziren mikrotomoan, eta, albumina erabiliz, beirazko portetan jarri ziren. 24 orduz lehortzen izan eta gero, $37^{\circ} \mathrm{C}$-an hematoxilina- eta eosina-tindaketa egin zen. Mikroskopioaren bidez, digestio-glandulako zelula motak, epitelioa eta egituran izandako aldaketak behatu ziren. Era berean, zelula basofilikoen bolumena, gonaden garapen-puntua, etab. behatu ziren.

\section{EMAITZAK ETA EZTABAIDA}

Atal hau hiru zati nagusitan banatu da. Alde batetik, muskuiluetako eta biltze-pasiboko metaketari dagozkion emaitzak; bestetik, azterketa metabolikoari dagozkionak, eta, azkenik, histologia-azterketatik lortutako emaitza esanguratsuenak.

\subsection{Muskuiluen metaketa eta lagin-biltze pasiboaren bidezko jarraipena}

Lan esperimental honetan, aldi berean, bi eginkizun bete ziren: lagin biltze pasiboaren kalibrazioa SBa (hagatxo birakaria, stir-bar) erabiliz eta baldintza bereko muskuiluen esposizioa. Horrez gain, beste saiakera batean, muskuiluen esposizioa modu ez-jarraituan egin zen, eta horretan neurtutako metaketaren berri emango da. Lagin-biltze pasiboari dagokionez, SBei dagozkien biltze- edo xurgatze-abiadurak $\left(\mathrm{R}_{\mathrm{s}}\right.$, sampling rate,

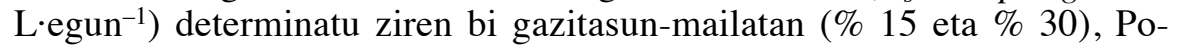
sada-Ureta et al.ek (2016) [44] adierazi zuten bezala, eta lortutako $\mathrm{R}_{\mathrm{s}}$-en 
emaitzak. Aurretiaz publikatutako emaitzak beharrezkoak izan dira lan honetako emaitzak eskuratzeko.

Lehen eta hirugarren saiaketetan, esposizio ez-jarraituan (1. esperimentua) eta $20 \mathrm{ng} \mathrm{L}^{-1}$-eko esposizio jarraituan (3. esperimentuan) hain zuzen, kutsatzaile organikoen kontzentrazioak determinatu ziren muskuiluetan. Emaitza horiek 1. taulan laburbildu dira. Taulan ikus daitekeen bezala, muskuiluetan bildutako analitoen kontzentrazioak oso bestelakoak dira. Kontzentrazio-maila altuenak DDD, DDE eta DDTaren kasuetan neurtu ziren.

1. taula. 1. eta 3. esperimentuetako (e eguna izanik) muskuiluetan neurtutako kutsatzaileen kontzentrazioen laburpena ( $\mathrm{ng} \mathrm{g}^{-1}$ ), dagokien desbideratze estandarrarekin (esperimentala)

\begin{tabular}{lccccccc}
\hline \multicolumn{1}{c}{ Saiaketa } & HHCB & AHTN & Clorp & $4,4-\mathrm{DDE}$ & 2,4-DDD & $4,4-\mathrm{DDD}$ & 4,4-DDT \\
\hline $\mathrm{Cw}, 1.000 \mathrm{ngL}^{-1}$ & $49 \pm 7$ & $42 \pm 8$ & $31 \pm 44$ & $499 \pm 44$ & $539 \pm 49$ & $713 \pm 6$ & $7556 \pm 2546$ \\
$\mathrm{Cw}, 100 \mathrm{ngL}^{-1}$ & $11,2 \pm 0,5$ & $6 \pm 3$ & $28 \pm 5$ & $64 \pm 5$ & $71 \pm 10$ & $99 \pm 11$ & $603 \pm 66$ \\
$\mathrm{Cw}, 10 \mathrm{ngL}^{-1}$ & $9,2 \pm 0,4$ & $2,29 \pm 0,07$ & $15 \pm 6$ & $8,4 \pm 0,2$ & $5,91 \pm 0,08$ & $7,6 \pm 0,3$ & $47,9 \pm 0,6$ \\
$\mathrm{Cw}, 20 \mathrm{ngL}^{-1}, 3 \mathrm{e}$ & $6 \pm 1$ & $2,1 \pm 0,2$ & $11,0 \pm 0,4$ & $12,0 \pm 0,7$ & $29 \pm 1$ & $15 \pm 1$ & $22 \pm 1$ \\
$\mathrm{Cw}, 20 \mathrm{ngL}^{-1}, 7 \mathrm{e}$ & $8,8 \pm 0,4$ & $2,7 \pm 0,2$ & $23 \pm 2$ & $15,5 \pm 0,8$ & $41 \pm 1$ & $17,4 \pm 0,9$ & $30 \pm 2$ \\
$\mathrm{Cw}, 20 \mathrm{ngL}^{-1}, 14 \mathrm{e}$ & $10 \pm 1$ & $4 \pm 0,2$ & $32 \pm 1$ & $17,4 \pm 0,6$ & $46 \pm 2$ & $20 \pm 2$ & $45 \pm 5$ \\
\hline
\end{tabular}

Lehen saiaketari dagokionez, emaitza guztiak 14 eguneko esposizioaren ondorengoak dira, eta lortutako kontzentrazioak ikusita, haien arteko erlazioak aztertu ziren. Izan ere, metaketa egoera iraunkorrean gertatuko balitz, hau da, denborarekiko joerarik gabe, eta uretako kontzentrazioa 10 aldiz handiagotu ostean, muskuiluetako kontzentrazioak ere modu berean egin beharko luke gora. Hori horrela balitz, kontzentrazio nominalak 10etik 100era edo 100etik 1.000ra igaro ondoren, hamar aldiko jauziak nabarmendu beharko genituzke muskuiluetan eta 10etik 1.000ra, aldiz, 100 aldiko jauzia. Erlazio esperimental guztiak 5. irudian irudikatu dira, eta, ikus daitekeen bezala, espero ziren jauziak soilik betetzen dira DDT eta haren eratorriekin. Musketekin eta klorpirifosekin, ordea, jauziak espero zirenak baino askoz apalagoak izan ziren.

Lortutako emaitzak azaltzeko hurbilketa bi aurkitu ditugu. Alde batetik, muskuiluen metaketa egoera iraunkorretik urrun izatea, eta, beraz, oraindik nolabait ase gabe izatea, eta, bestetik, uretako kontzentrazioa nominala baino baxuagoa izatea, hormetan eta hodietan eta abarretan atxiki ondoren. 


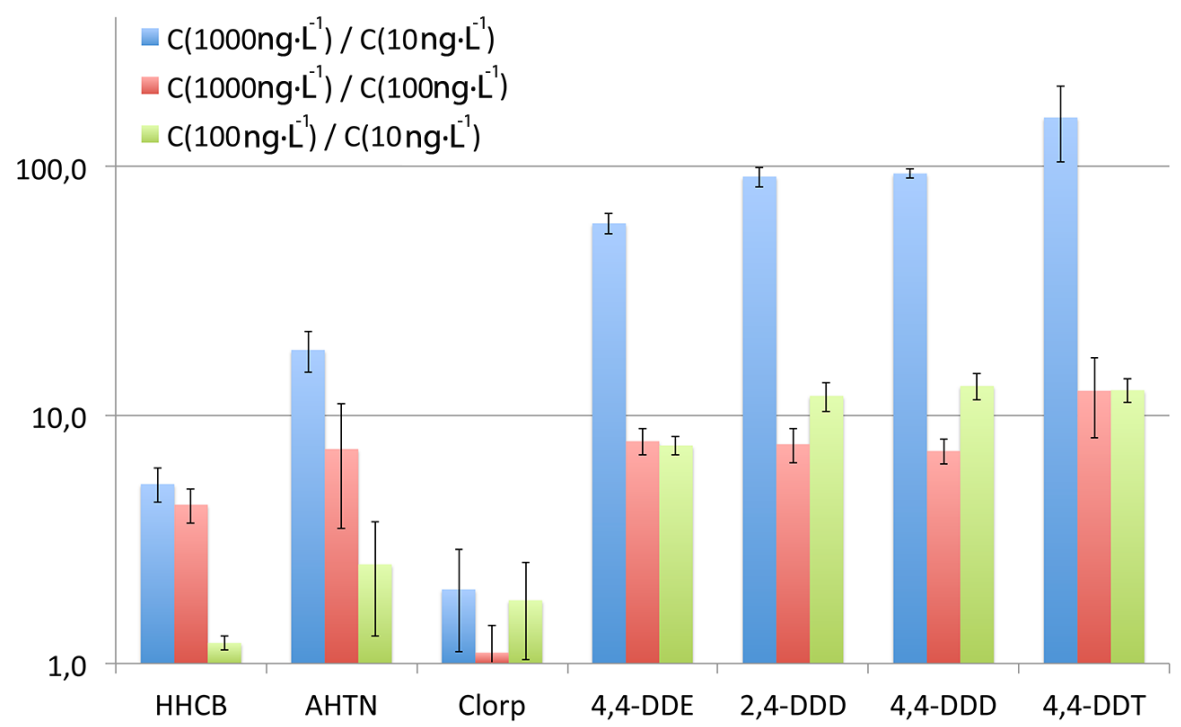

5. irudia. 1. esperimentuko kontzentrazioen proportzioak, kontzentrazioa 10 aldiz eta 100 aldiz handiagotzean, dagokien desbideratze estandarrarekin.

Nolanahi ere, 2. taulan, honako balio hauek bildu dira: DDT eta haren eratorrien muskuiluetan neurtutako kontzentrazioen eta uretako kontzentrazio esperimentalen arteko erlazio logaritmikoak (log BCF), erreferentzietan muskuiluen kasurako aurkitutako balio esperimentalak [45] eta EPA Suite delakoaren bidez estimatutako balio teorikoak, ChemSpider-tik eskuragarriak [19]. Ikusten denez, balio esperimentalak, doiak izan arren, erreferentzietatik behera daude. Ziurrenik, kasu horietan ere, kontzentrazio nominala ez da izan benetakoa eta, saiaketa berak ere ura aldizka aldatu beharra zuenez, espero ziren balioetatik urrun aurkitu ziren kontzentrazioak. Kutsatzaile-esposizioaren metodologiak edo protokoloak, hau da, aldizkakoa edo jarraitua izateak, eragin argia du.

2. taula. 1. esperimentuko kutsatzaileen kontzentrazioaren eta uretako kontzentrazioaren arteko erlazio logaritmikoa (log $\mathrm{BCF})$, dagokien desbideratze estandarrarekin.

\begin{tabular}{|c|c|c|c|c|}
\hline & 4,4-DDE & 2,4-DDD & 4,4-DDD & 4,4-DDT \\
\hline $\log$ BCF $1.000 \mathrm{ng} \mathrm{L}^{-1}$ & $2,71 \pm 0,04$ & $2,74 \pm 0,04$ & $2,86 \pm 0,01$ & $3,9 \pm 0,1$ \\
\hline $\log$ BCF $100 n^{-1}$ & $2,81 \pm 0,04$ & $2.86 \pm 0,06$ & $3,01 \pm 0,05$ & $3,79 \pm 0,05$ \\
\hline $\log \mathrm{BCF} 10 \mathrm{ng} \mathrm{L}^{-1}$ & $2,94 \pm 0,01$ & $2.78 \pm 0,01$ & $2,89 \pm 0,02$ & $3,69 \pm 0,01$ \\
\hline $\log \mathrm{BCF}_{\mathrm{esp}}$ & $3,70-4,30$ & $3,96-4,42$ & $3,96-4,42$ & 4,37 \\
\hline $\log \mathrm{BCF}_{\text {teor }}$ & 4,31 & 3,82 & 3,93 & 4,62 \\
\hline
\end{tabular}


Hala ere, BCF balio esperimentalen erkaketa egitea ez da horren zuzena, zeren, analitoaren ezaugarriez gain, matrize biologikoaren ezaugarriak ere behar baitira kontuan hartu. Asko aldatzen da proteina eta lipidoen proportzioa espeziaren, tamainaren, adinaren, jatorrizko tokiaren, ugalketa-mailaren eta baita urtaroaren edo garaiaren arabera. Izan ere, iragazte-ratioa, izandako elikadura eta aipatutako faktore horiek guztiak zuzenki erlazionatuta daude muskuiluek izaten dituzten BCF balioekin.

Hirugarren saiaketako emaitzek denboraren araberako neurriak zituzten, eta datu horietan oinarrituz BCF balio esperimentalak eta denborarekiko mendetasuna aztertu ziren. Kasu horretan nabarmendu zen 3. egunetik 14. egunerako bitartean balioak gero eta handiagoak egiten zirela modu lineal batera hurbiltzean; beraz, argi zegoen BCF balioak ez zirela egoera iraunkor batera egokitu zirenak. Hori zela eta, lagin-biltze pasiboan oinarritutako azterketa zinetiko bat egin zen.

Metaketari dagokion eredurik sinpleena atal bakarrekoa da, eta haren metaketaren adierazpena hauxe da:

$$
C_{m u s k}(t)=C_{w} \frac{k_{1}}{k_{2}}\left(1-e^{-k_{2} t}\right),
$$

non $\mathrm{C}_{\text {musk }}$ eta $\mathrm{C}_{w}$ baitira, hurrenez hurren, muskuiluetan eta uretan dauden kontzentrazioak; $\mathrm{k}_{1}$ eta $\mathrm{k}_{2}$, metaketaren eta eliminazioaren abiadura konstanteak, hurrenez hurren, eta $t$, igarotako denbora. Muskuilua metaketa egoera iraunkorretik urrun bada, eliminazioa arbuiagarria da metaketarekiko; beraz, adierazpen hori honelaxe laburtu ahal da:

$$
C_{\text {musk }}=C_{w} k_{1} t .
$$

Azken ekuazio hori aplikatu zen SBen emaitzetan, non SB bakoitzak metatutako masa (ng-tan) determinatu zen esperimentalki eta SB bakoitzak zuen PDMSko bolumenetik eta haren dentsitatetik $(47 \mu \mathrm{L}$ eta $965 \mathrm{~kg} \cdot \mathrm{m}^{3}$ ) SBtako kontzentrazioak ziren. Modu bertsuan muskuiluetako kontzentrazioak kalkulatu zirenez, bien erlazioa $\left(\mathrm{C}_{\text {musk }}\right.$ eta $\left.\mathrm{C}_{\mathrm{SB}}\right)$ denborarekiko irudikatu zen 6. irudian 2,4-DDDren kasuan. Kasu bietan uretako kontzentrazioa $\left(\mathrm{C}_{\mathrm{W}}\right)$ bera eta ezaguna izan zenez, irudi horietatik kalkulatu genituen metaketa konstantearen balioak $\left(\mathrm{k}_{1}\right.$, malda) eta haien balioak 3. taulan bildu dira, doiketaren erregresio koefizienteekin batera.

Muskuiluen metaketa SBena baino askoz mantsoagoa izan arren, emaitzak ondo doitzen dira eredu sinple berera, eta beraz, batean hautematen diren ondorioak besteari egokitu ahal zaizkio. 


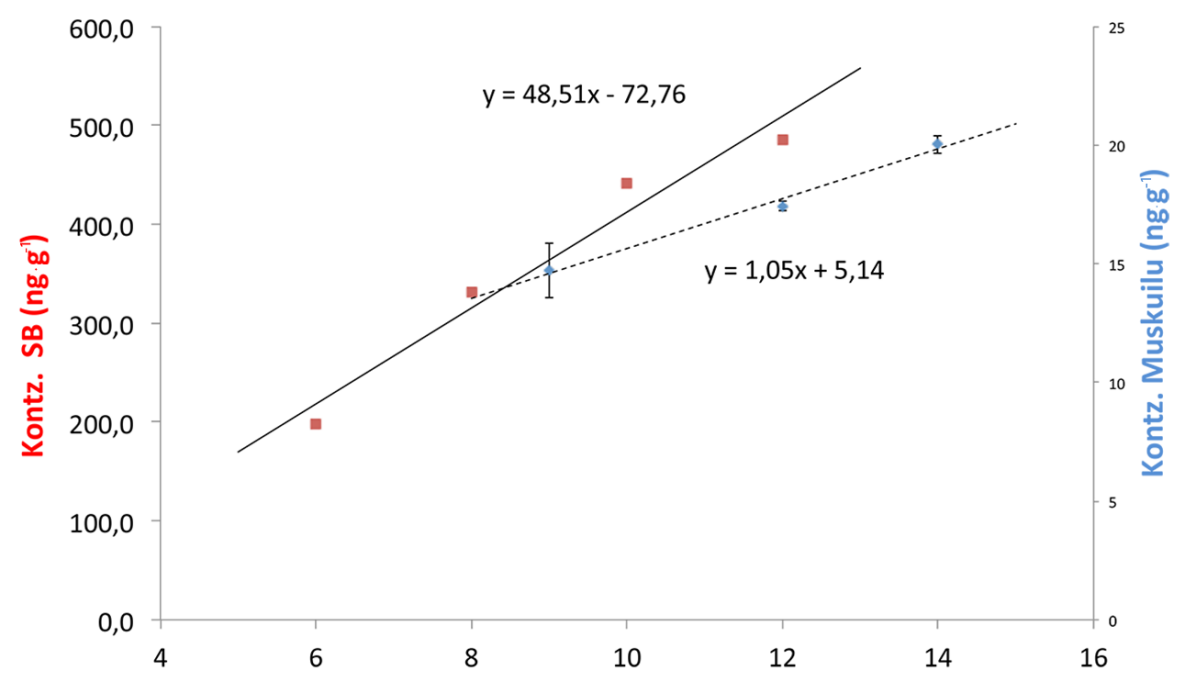

6. irudia. Zinetikoki SBek eta muskuiluek zuten jokamoldearen erakusgarri 2,4DDDren adibidea.

3. taula. Zinetikaren azterketa: muskuiluen eta SBen konparaketa.

\begin{tabular}{lrrrrrc}
\hline & HHCB & AHTN & Clorp & 4,4-DDE & 2,4-DDD & 4,4-DDD \\
\hline malda muskuilu $\left(\mathrm{k}_{1}\right.$, egun $\left.^{-1}\right)$ & 0,75 & 0,29 & 4,28 & 1,08 & 3,37 & 1,05 \\
$\mathrm{R}^{2}$ muskuilu & 1,00 & 0,95 & 1,00 & 1,00 & 0,98 & 0,99 \\
malda SB $\left(\mathrm{k}_{1}\right.$, egun $\left.^{-1}\right)$ & 58,43 & 62,84 & 62,84 & 22,05 & 48,51 & \\
$\mathrm{R}^{2} \mathrm{SB}$ & 0,97 & 0,98 & 0,99 & 0,98 & 0,98 & \\
\hline
\end{tabular}

\subsection{NMR metabolomika}

NMRko analisiak hemolinfan, oinetan eta gonadetan egin ziren, eta emaitzen erakusgarri gisa 3. esperimentua aukeratu da. Behin metabolito hidrofilikoei dagozkien NMR espektroak jasota, kimiometria erabili zen emaitzak aztertzeko. Aldakortasun biologikoa oso handia agertzen dute muskuilu basatiek. Hori dela eta, OPLS-DA bezalako analisi-baliabideak beharrezkoak izan ziren faktore naturalen eragina murrizteko eta guk eragindako estres-faktorearen eragina azaleratzeko.

\subsubsection{3. esperimentuko emaitzak}

Jariakinaren eta ehunen analisi kimiometrikoa egin ostean, emaitzak bateratu, eta interpretazio bateratua ematen saiatu ginen. Behin metabo- 
litoen seinaleen esleipena egiaztatuta, VIPen tauletan batu genituen zenbait metabolito interesgarri. Interpretazioa errazteko asmoz, kontrolarekiko adierazi genituen seinaleak eta metabolitoen joerak koloreen bitartez adierazi genituen beromapetan (heatmap).

\section{(i) Hemolinfa}

Hemolinfa-laginekin eraikitako OPLS-DA ereduan 3 osagai nagusi erabili ditugu x matrizearen $\% 45,55$ eko bariantza eta y matrizearen $\%$ 82,19ko bariantza azaltzeko.

7. irudiko scores-etan, lehen osagaiak 7. eguneko klasea kontroletik eta 3. eguneko klasetik bereizten ditu. Bigarren osagaiak, kontrola 3. eguneko datuetatik bereizten laguntzen du. 4. taulan adierazitako VIPek agerian uzten dituzte 7. eguneko klasean homarina eta betaina bezalako osmolitoen igoerak. 3. Egunean aipagarria da VIPetan adierazitako metabolito gehienen aldaketa nabarmena ageri zela.

4. taula. $20 \mathrm{ng} \mathrm{L}^{-1}$-eko esperimentuan jasotako hemolinfen klaseak ezaugarritzen dituzten VIPetako metabolito garrantzitsuenen aldaketak laburbiltzen dituen taula. Datuak kontrolarekiko adierazita daude eta euren joerak errazago interpretatzeko koloreztatuak daude (berdez balio txikiagoak eta gorriz altuagoak).

\begin{tabular}{lcccc}
\hline \multicolumn{1}{c}{ Metabolitoa } & ppm & E1_H_kontrola & E2_H_3egun & E3_H_7egun \\
\hline leuzina/isoleuzina & 0,953 & 1,00 & 1,34 & 0,06 \\
metilmalonatoa & 1,248 & 1,00 & 0,49 & 1,48 \\
laktatoa & 1,335 & 1,00 & 1,42 & 0,23 \\
alanina & 1,485 & 1,00 & 1,65 & 0,12 \\
azetatoa/azetoazetatoa & 1,923 & 1,00 & 1,91 & 0,71 \\
ornitina & 1,935 & 1,00 & 2,73 & 0,25 \\
pirubatoa & 2,402 & 1,00 & 0,43 & 1,55 \\
sukzinatoa & 2,424 & 1,00 & 1,80 & 0,10 \\
aspartatoa & 2,849 & 1,00 & 1,70 & 0,06 \\
kolina & 3,204 & 1,00 & 0,82 & 1,11 \\
glizerofosfokolina & 3,222 & 1,00 & 1,35 & 0,92 \\
fosfokolina & 3,227 & 1,00 & 0,91 & 1,19 \\
betaina & 3,276 & 1,00 & 0,44 & 1,55 \\
glukosa & 3,424 & 1,00 & 0,42 & 1,54 \\
glizina & 3,557 & 1,00 & 2,03 & 0,23 \\
homarine & 4,364 & 1,00 & 0,44 & 1,56 \\
ATP/ADP & 8,542 & 1,00 & 2,18 & 0,11 \\
\hline
\end{tabular}




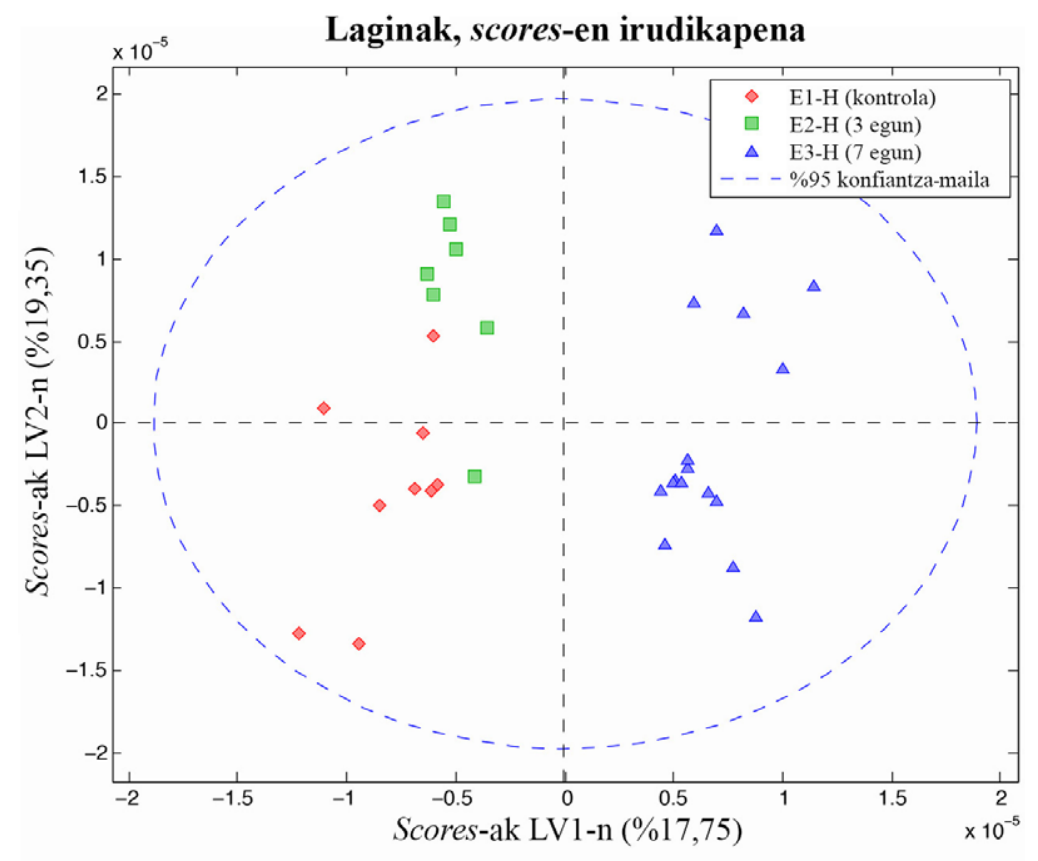

Aldagaiak, loadings-en irudikapena

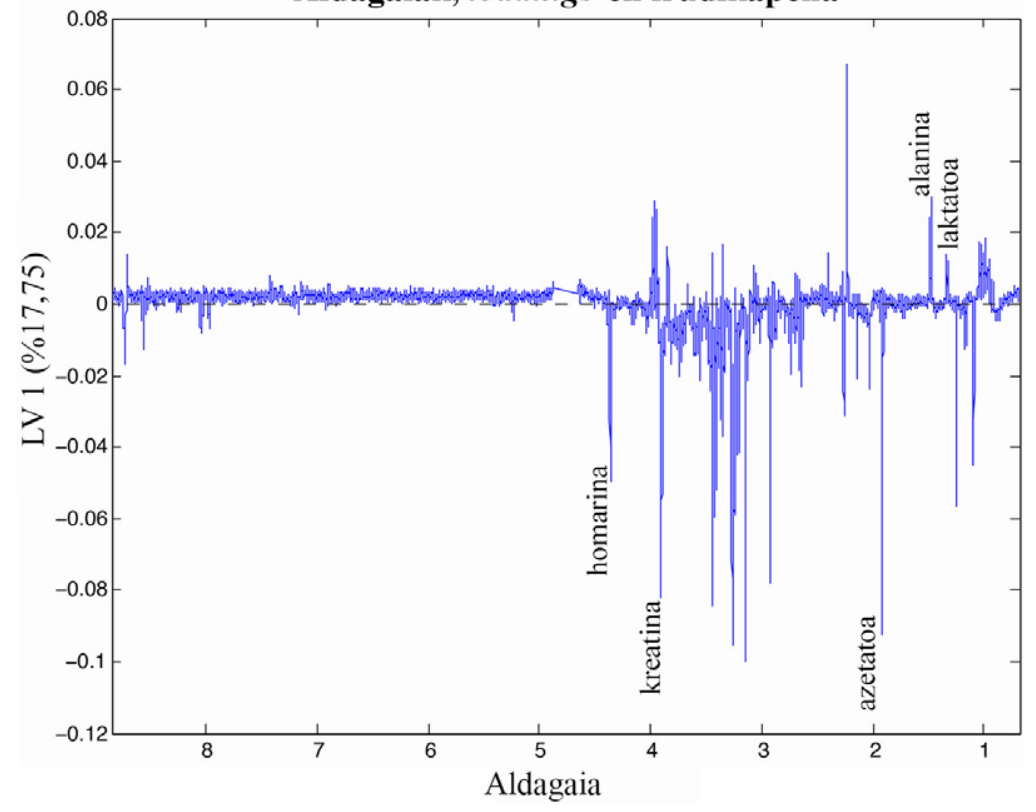

7. irudia. 3. esperimentuko hemolinfa-datuekin eraikitako OPLS-DA ereduaren scores-ak (goikoa) eta loadings-ak (behekoa). 
(ii) Gonada

Gonadaren kasuan 3. eguneko zenbait lagin baztertu behar izan genituen arazo teknikoak direla kausa, eta 2 lagin bakarrik ditugu klase hau azaltzeko. OPLS-DA eredua, 8. irudian ikusten den bezala, kontrol-taldeak distortsionatzen du, kontrol-taldea gainerako taldeekin konparatuz oso ezberdina delako. 8. irudiko OPLS-DA ereduak x matrizearen \% 54,32ko bariantza eta y matrizearen \% 36,70eko bariantza azaltzen du.

5. taulan adierazi dira ereduaren VIPetatik eskuratutako metabolitorik esanguratsuenak. Aldaketarik nabariena 3. egunean dugu, hots, kreatina, $\alpha-$ zetoglutarato, metilmalonato, fosfokreatina, serina eta hidroxibutirato metabolitoen igoera handienak. Guztiak estres-egoera horren erantzun gisa azaldu ahal dira.

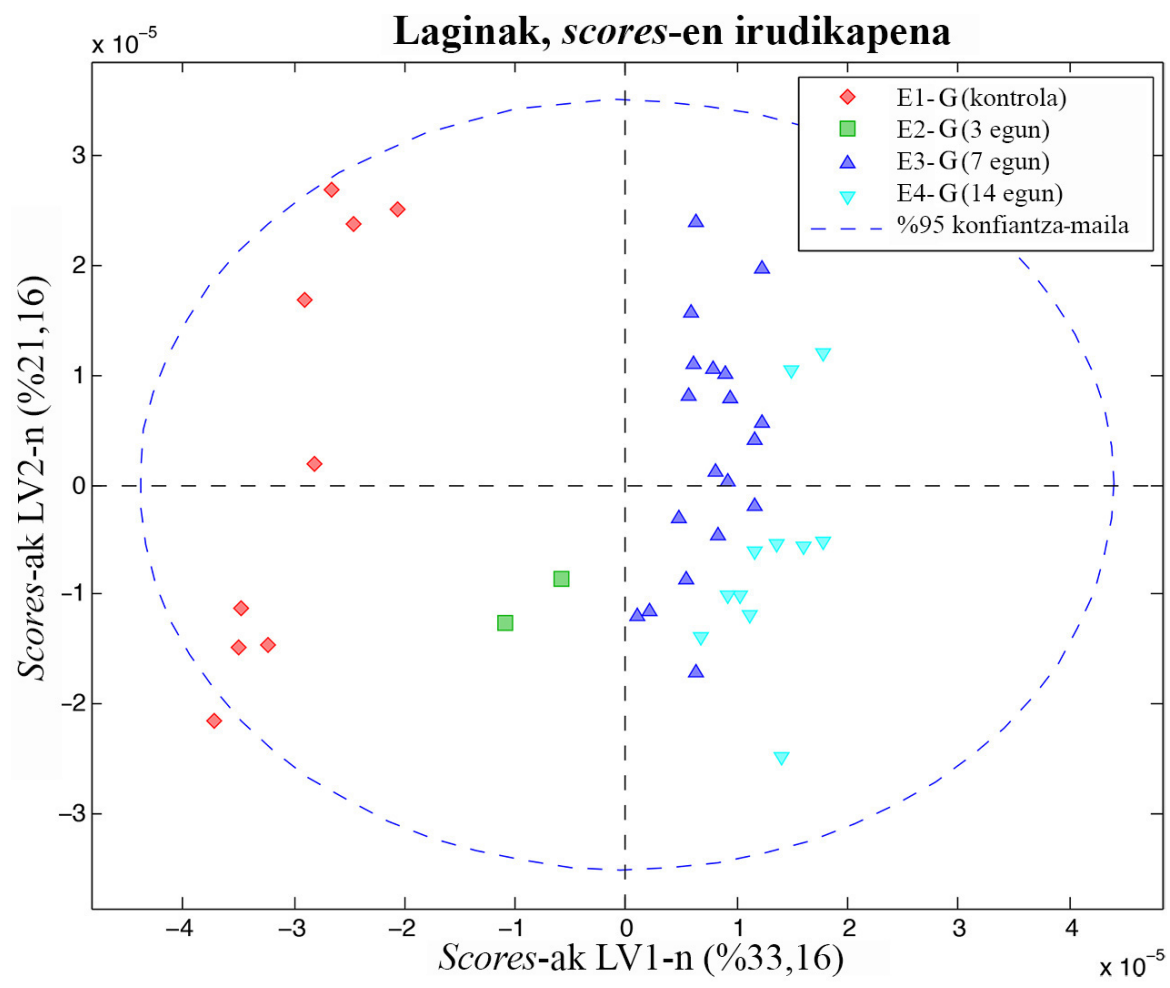

8. irudia. 3. esperimentuko gonaden datuekin eraikitako OPLS-DA ereduaren scores-ak. 
(iii) Oina

Azkenik, oinaren eredua aipatuko dugu. OPLS-DA eredua eraikitzeko 2 PC erabili dira x matrizearen $\% 51,11$ ko bariantza eta y matrizearen $\%$ 49,83ko bariantza azaltzeko.

5. taula. $20 \mathrm{ng} \mathrm{L}^{-1}$-eko esperimentuan jasotako gonaden klaseak ezaugarritzen dituzten VIPetako metabolito garrantzitsuenen aldaketak laburbiltzen dituen taula. Datuak kontrolarekiko adierazita daude eta euren joerak errazago interpretatzeko koloreztatuta daude (berdez balio txikiagoak eta gorriz altuagoak).

\begin{tabular}{lcc|c|c|c}
\hline \multicolumn{1}{c}{ Metabolitoa } & ppm & E1_G_kontrola & E2_G_3egun & E3_G_7egun & E4_G_14egun \\
\hline leuzina/isoleuzina & 0,961 & 1,00 & 3,87 & 1,82 & 2,07 \\
balina & 0,980 & 1,00 & 1,79 & 1,23 & 1,30 \\
\hline D-3-hidroxibutiratoa & 1,180 & 1,00 & 18,14 & 5,88 & 7,41 \\
\hline laktatoa & 1,333 & 1,00 & 0,61 & 0,89 & 0,85 \\
\hline alanina & 1,471 & 1,00 & 1,76 & 0,87 & 0,82 \\
\hline azetatoa/azetoazetatoa & 1,915 & 1,00 & 13,88 & 4,66 & 5,82 \\
glutamatoa & 2,060 & 1,00 & 0,68 & 0,91 & 0,88 \\
pirubatoa & 2,400 & 1,00 & 5,58 & 2,30 & 2,71 \\
hipotaurina & 2,659 & 1,00 & 0,45 & 0,84 & 0,80 \\
aspartatoa & 2,824 & 1,00 & 2,63 & 1,46 & 1,61 \\
a-zetoglutaratoa & 3,010 & 1,00 & 31,55 & 9,69 & 12,43 \\
kreatinina & 3,023 & 1,00 & 30,90 & 9,51 & 12,18 \\
zisteina & 3,112 & 1,00 & 0,47 & 0,85 & 0,80 \\
metilmalonatoa & 3,177 & 1,00 & 6,41 & 2,54 & 3,02 \\
kolina & 3,203 & 1,00 & 0,58 & 0,88 & 0,84 \\
glizerofosfokolina & 3,226 & 1,00 & 0,79 & 0,94 & 0,92 \\
fosfokolina & 3,226 & 1,00 & 0,93 & 0,98 & 0,98 \\
betaina & 3,277 & 1,00 & 1,14 & 1,04 & 1,05 \\
taurina & 3,284 & 1,00 & 5,88 & 2,39 & 2,83 \\
glukosa & 3,423 & 1,00 & 0,38 & 0,82 & 0,77 \\
glizina & 3,567 & 1,00 & 3,97 & 1,84 & 2,11 \\
serina & 3,845 & 1,00 & 15,29 & 5,07 & 6,35 \\
fosfokreatina & 3,951 & 1,00 & 29,64 & 9,15 & 11,71 \\
ATP/ADP & 8,543 & 1,00 & 0,33 & 0,81 & 0,75 \\
\hline ezezaguna & 8,700 & 1,00 & 28,29 & 8,76 & 11,21 \\
\hline & & & & & \\
\hline
\end{tabular}


9. irudian, lehen osagaiak bi talde nagusi banatzen dituela ikus dezakegu: kontrola eta 3. eguneko lagina, batetik, eta 7. eta 14. egunetako laginak, bestetik. Bigarren osagaiak, ordea, kontrola 3. eguneko laginetik, eta 7. egunekoa 14. egunekotik banatzen ditu.

6. taulan ikus daitekeen bezala, oinean aurkitutako aldaketa adierazgarrienak, hots, fosfokolina, taurina, aspartatoa eta azetato metabolitoen igoera handienak.

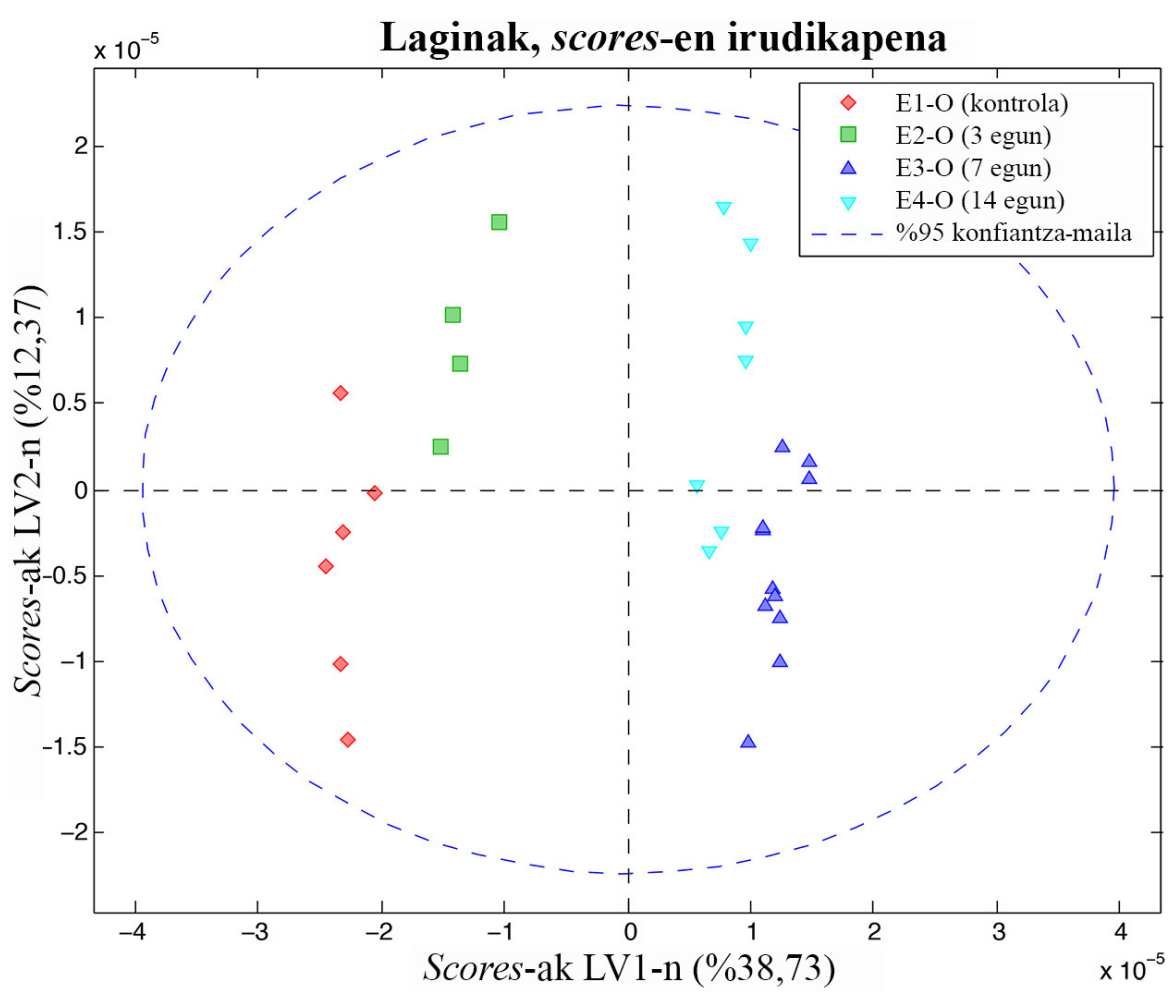

9. irudia. 3. esperimentuko oinen datuekin eraikitako OPLS-DA ereduaren scores-ak. 
6. taula. 20ng $\mathrm{L}^{-1}$-eko esperimentuan jasotako oinen klaseak ezaugarritzen dituzten VIPetako metabolito garrantzitsuenen aldaketak laburbiltzen dituen taula. Datuak kontrolarekiko adieraziak daude eta euren joerak errazago interpretatzeko koloreztatuta daude (berdez balio txikiagoak eta gorriz altuagoak).

\begin{tabular}{lccccc}
\hline \multicolumn{1}{c}{ Metabolitoa } & ppm & E1_O_kontrola & E2_O_3egun & E3_O_7egun & E4_O_14egun \\
\hline alanina & 1,478 & 1,00 & 0,63 & 0,84 & 0,60 \\
azetatoa/azetoazetatoa & 1,921 & 1,00 & 5,60 & 2,99 & 6,04 \\
ornitina & 1,935 & 1,00 & 0,48 & 0,77 & 0,43 \\
pirubatoa & 2,409 & 1,00 & 1,54 & 1,23 & 1,59 \\
zitratoa & 2,639 & 1,00 & 1,17 & 1,07 & 1,19 \\
hipotaurina & 2,667 & 1,00 & 0,50 & 0,78 & 0,45 \\
aspartatoa & 2,809 & 1,00 & 2,47 & 1,64 & 2,61 \\
asparagina & 2,928 & 1,00 & 0,97 & 0,99 & 0,97 \\
zisteina & 3,114 & 1,00 & 0,48 & 0,77 & 0,43 \\
histidina & 3,146 & 1,00 & 0,60 & 0,83 & 0,56 \\
metilmalonatoa & 3,192 & 1,00 & 2,72 & 1,75 & 2,89 \\
kolina & 3,208 & 1,00 & 1,07 & 1,03 & 1,08 \\
glizerofosfokolina & 3,224 & 1,00 & 0,58 & 0,82 & 0,53 \\
fosfokolina & 3,227 & 1,00 & 3,00 & 1,87 & 3,20 \\
betaina & 3,270 & 1,00 & 0,53 & 0,79 & 0,48 \\
taurina & 3,280 & 1,00 & 5,43 & 2,92 & 5,86 \\
glukosa & 3,415 & 1,00 & 0,47 & 0,77 & 0,42 \\
glizina & 3,564 & 1,00 & 1,29 & 1,13 & 1,32 \\
homarina & 4,371 & 1,00 & 0,53 & 0,80 & 0,49 \\
ATP/ADP & 1,00 & 0,51 & 0,79 & 0,46 \\
\hline & & & & \\
\hline
\end{tabular}

Ondorioak ateratzeko orduan, lehentasuna eman diegu gonadekin eta oinekin lortutako emaitzei. Izan ere, hemolinfa hartzeko eskarmentu berezia izan behar zen, zeren eta arrisku handia baitzegoen ehunetako zelula asko (obozitoak, muskuluko zelulak, eta abar) jaso izana, eta horiek zorizko artefaktu asko sar zitzaketela uste dugu. Gainera, jasotako hemolinfa bolumenean zaila da errepikakorra izatea. Honetaz gain, 14. eguneko hemolinfa-laginekin arazoren bat izan genuen: VIPak aztertzerakoan 14. eguneko eta kontroleko VIPak oso antzekoak zirela ohartu ginen, nahiz eta la- 
ginen kudeaketan eta tratamenduan arazorik hauteman ez genuen; beraz, 14. eguneko taldea eredutik kentzea erabaki genuen.

Aldaketa handiena, 3. egunean ikusi genuen, oinean, gonadan zein hemolinfan. Aldaketa nabarmenena, hala ere, gonadan atzeman zen; ondoren oinean, eta azkenik hemolinfan. Aipatu beharra dugu 3. egunean errutea gertatu zela, eta gertaera horrek azal ditzake egun horretan bereziki hautemandako aldaketa metabolikoak.

Kontrolarekin konparatuta, kutsatzaileen eraginpean izandako laginek hidroxibutiratoaren, azetatoaren, taurinaren, kreatinaren eta $\alpha$-zetoglutaratoaren mailetan igoera handiak agertu zituzten. Hidroxibutirato-, azetatoeta kreatina-mailen igoerak hantura orokorraren adierazle metabolikoak izaten dira. Aminoazidoen kontzentrazioek ere gora egin zuten, baina glutamatoaren, zisteinaren, glizinaren eta histidinaren mailak jaitsi egin ziren, oinean eta gonadan. Alaninaren eta aspartatoaren kasuan, ordea, oinean bakarrik hauteman zen metabolito hauen jaitsiera.

3. egunean ATP/ADPren mailan jaitsiera nabarmenena aurkitu genuen, gonadan bereziki. Ziur aski, energia-kontsumo hori errutearekin erlazionatuta dago. Energia-beharrizan hori agerian dago, glukosaren mailan ere hauteman baitugu jaitsiera.

Oro har, esposizioak aldaera nabariak ekarri ditu muskuiluetan. Alde batetik, kutsatzaileen metaketa garbia eta, bestetik, aldaketa metabolitko eta fisiologikoak.

\subsection{Analisi histopatologikoa}

Analisi histopatologikoak nagusiki digestio-glandulan eta gonadan aztertu ziren. Digestio-glandularen behaketak hainbat gaitz azaleratu zituen koktelaren kontzentrazio altuenetan: digestio-epitelioaren atrofia/metaplasia, digestio-dibertikuluaren egitura orokorraren desegonkortzea, digestiozelulen bakuolizazioa, identifikatu gabeko gorputz eosinofiloen presentzia, digestio-tubuluen inguruko ehun konektiboetako infiltrazio hemozitikoa eta granulozitomak.

Hala ere, muskuiluetan hauteman zen ondoriorik larriena errute goiztiarra izan zen. Ugaltze-zikloan kutsatzaileen koktelak eragin zuzena izan zuela argi ikus daiteke 10. irudian. Muskuiluek, estres-egoera handian daudenean, errutea dute erantzun ohiko bat, egoera aktibo batetik pasiboago batera joateko bizirauteko asmo bakarrarekin. 

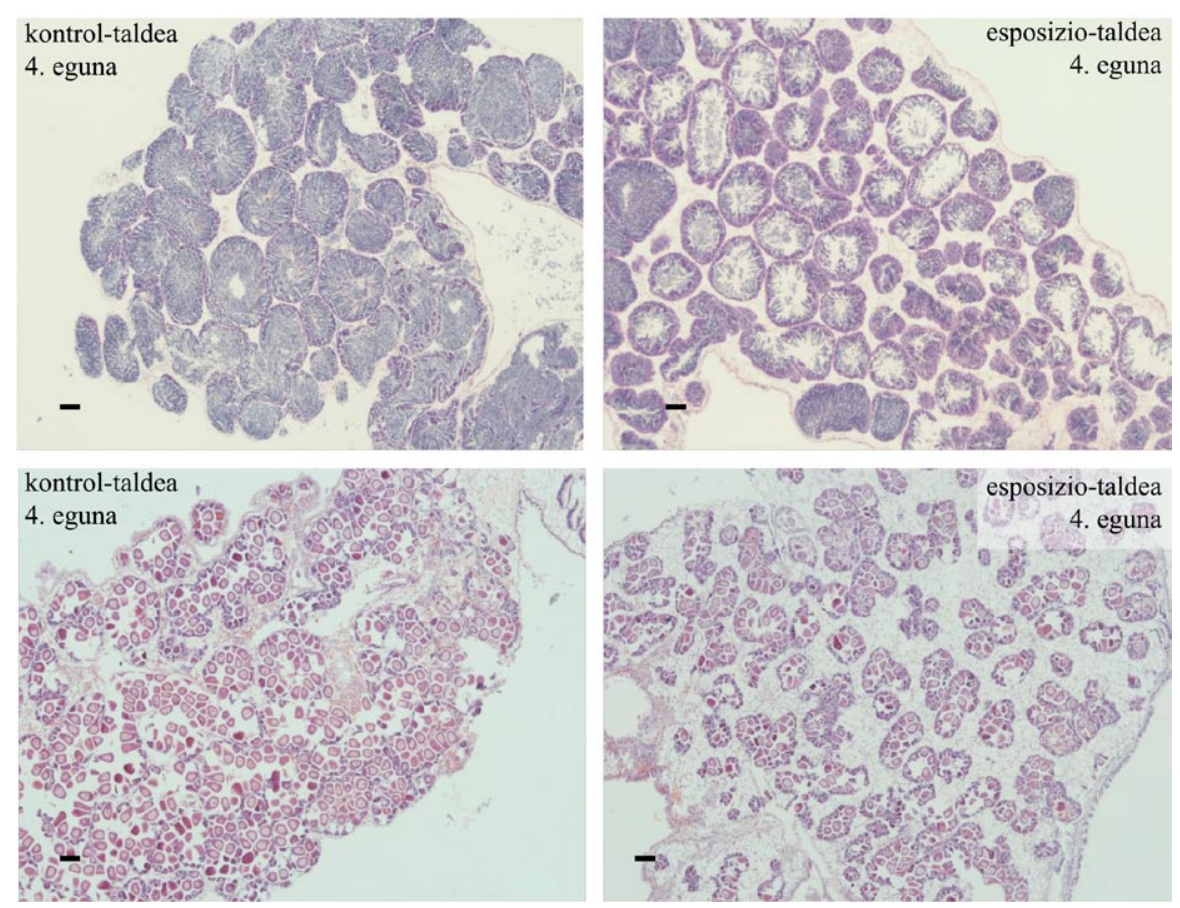

10. irudia. Gonaden hematoxilina- eta eosina-tindaketaren ondoren lortutako irudiak; gonaden garapenean, errute goiztiarra da aldaketa nabarmena.

\section{ONDORIOAK}

Laginketa pasiboaren bitartez itsasadarretako kutsatzaileen kontzentrazioak neurtzeko metodologia taxutu da lan honetan. Horretarako, laginketa pasiboa oso egokia da, baina muskuiluak metatutakoarekin alderatuz gero, laginketa pasiboaren bitartez neurtutako kontzentrazioak ez datoz bat. Erraza da azaltzea azken gertaera hau. Laginketa aktiboan, kutsatzaileak milaka mekanismo eta bide metabolikoren mende daude organismoan, eta kutsatzaileek eraldaketak eta kanporatzeak jasan ditzakete. Muskuiluek, aktibo daudenean, $30 \mathrm{~mL}$ ur· $\mathrm{min}^{-1}$-eko iragazten dute; aitzitik, laginketa pasiboko tresneria inguruko urarekin izango du soilik kontaktua (laginketa pasiboko tresneriaren kontaktu hau handitzeko, karrusel birakarian kokatu dira). Bi neurketa mota horietatik, informazio osagarria eskuratzen dugu, laginketa pasiboak argi erakutsi baitu oso aproposa dela denboran zehar gertatutako kutsatzaileen kontzentrazioa neurtzeko. Gainera, ur oso kutsatua analizatu beharko bagenu, muskuiluek ez lukete ezertarako balio izango, hil egingo liratekeelako, eta kasu horietan, laginketa pasiboa oso interesgarria litzateke. 
Muskuiluen analisiari dagokionez, 2,4-DDD konposatua aurkitu da kontzentrazio altuenean. Uretako kutsatzaile horren kontzentrazioa igotzean, proportzionalki igotzen da muskuiluko kontzentrazioa. Badirudi kutsatzaileen biokontzentrazioaren balioaren eta oktanol/ur partizio koefizientearen $\left(\log \mathrm{K}_{\mathrm{ow}}\right)$ balioaren artean korrelazioa dagoela, zenbat eta $\log \mathrm{K}_{\mathrm{ow}}$ balio altuagoa izan kutsatzaileak, gehiago metatzen da muskuiluan.

Metabolomika oso lanabes erabilgarri eta interesgarria da, eta gure sistemaren «osasun-egoera»ren berri ematen digu. Gainera, histopatologiako emaitzekin alderatuta, informazio gehiago lortzeko gai izan gara. Erantzun biologiko garrantzitsuena errute goiztiarra izan da, eta, metabolomikako emaitzak ikusita, esan dezakegu eragindako aldaketa metabolomikoek ugalketa-zikloan eragin zuzena dutela.

Amaitzeko, gure ustetan, planteatutako estrategia erabilgarria da, eta etorkizunean gure estuario eta itsasertzetan aplikatu nahi dugu.

\section{ESKER ONAK}

Egileok eskerrak eman behar dizkiegu Euskararen eta Etengabeko Prestakuntzaren arloko Errektoreordetzari doktoratu aurreko laguntzarengatik; UPV/EHUri doktoretza ondorengo laguntzarengatik; Ministerioari proiektu-laguntzarengatik (Nuevas metodologías para evaluar el impacto de los contaminantes emergentes en ecosistemas marinos y el consumo de alimentos proiektua, CTM2014-56628-C3-1-R), eta EJ-GVri «A motako ikerketa-talde kontsolidatua» laguntzarengatik (IBeA en medio ambiente físico, urbano construido, recursos naturales y salud, IT1213/19 eta IT-742-13). Bukatzeko, eskerrak eman nahi dizkiogu Isabel Collado doktoreari, (SGIker-UPV/EHU) NMRko neurketetan emandako laguntzarengatik.

\section{BIBLIOGRAFIA}

[1] SCHWARZENBACH, R.P., EGLI, T., HOFSTETTER, T.B., VON GUNTEN, U. eta WEHRLI, B. 2010. «Global water pollution and human health». Annual Review of Environment and Resources, 35, 109-136.

[2] RICHARDSON, S.D. eta KIMURA, S.Y. 2016. «Water analysis: Emerging contaminants and current issues». Analytical Chemistry, 88, 546-582.

[3] VRANA, B., PASCHKE, A. eta POPP, P. 2006. «Calibration and field performance of membrane- enclosed sorptive coating for integrative passive sampling of persistent organic pollutants in water». Environmental Pollution., 144, 296-307. 
[4] RIGÉT, F., VORKAMP, K., BOSSI, R., SONNE, C., LETCHER, R.J. eta DIETZ, R. 2016. «Twenty years of monitoring of persistent organic pollutants in Greenland biota. A review». Environmental Pollution. 217, 114-123.

[5] PETRIE, B., BARDEN, R. eta KASPRZYK-HORDERN, B. 2015. «A review on emerging contaminants in wastewaters and the environment: Current knowledge, understudied areas and recommendations for future monitoring». Water Research, 72, 3-27.

[6] GEISSEN, V., MOL, H., KLUMPP, E., UMLAUF, G., NADAL, M., VAN DER PLOEG, M., VAN DE ZEE, S.E.A.T.M. eta RITSEMA, C.J. 2015. «Emerging pollutants in the environment: A challenge for water resource management». International Soil and Water Conservation Research, $\mathbf{3}$, 57-65.

[7] SOARES, A., GUIEYSSE, B., JEFFERSON, B., CARTMELL, E. eta LESTER, J.N. 2008. «Nonylphenol in the environment: a critical review on occurrence, fate, toxicity and treatment in wastewaters». Environment International, 34, 1033-1049.

[8] DEVIER, M.H., LE MENACH, K., VIGLinO, L., DI GIOIA, L., LACHASSAGNE, P. eta BUDZINSKI, H. 2013.«Ultra-trace analysis of hormones, pharmaceutical substances, alkylphenols and phthalates in two french natural mineral waters». Science of the Total Environment, 443, 621632.

[9] ORTIZ-ZARRAGOITIA, M., BIZARRO, C., ROJO-BARTOLOME, I., DIAZ DE CERIO, O., CAJARAVILLE, M. P., eta CANCIO, I. 2014. «Mugilid fish are sentinels of exposure to endocrine disrupting compounds in coastal and estuarine environments». Marine Drugs, 12, 4756-4782.

[10] SALGUEIRO-GONZALEZ, N., TURNES-CAROU, I., MUNIATEGUILORENZO, S., LOPEZ-MAHIA, P. eta PRADA-RODRIGUEZ, D. 2013. «Membrane assisted solvent extraction coupled with liquid chromatography tandem mass spectrometry applied to the analysis of alkylphenols in water samples». Journal of Chromatography A, 1281, 46-53.

[11] RIVADENEIRA, P.R., AGRELO, M., OTERO, S. eta KRISTOFF, G. 2013. «Different effects of subchronic exposure to low concentrations of the organophosphate insecticide chlorpyrifos in a freshwater gastropod». Ecotoxicology and Environmental Safety., 90, 82-88.

[12] JURADO, A., VÁZQUEZ-SUNÉ, E., CARRERA, J., LÓPEZ DE ALDA, M., PUJADES, E. eta BARCELÓ, D. 2012. «Emerging organic contaminants in groundwater in Spain: A review of sources, recent occurrence and fate in a european context». Science of the Total Environment, 440, 82-94.

[13] TURGUT, C. 2003.«The contamination with organochlorine pesticides and heavy metals in surface water in Kucuk Menderes river in Turkey, 20002002». Environment International, 29, 29-32.

[14] GULER, G.O., CAKMAK, Y.S., DAGLI, Z., AKTUMSEK, A. eta OZPARLAK, H. 2010. «Organochlorine pesticide residues in wheat from Konya region, Turkey». Food and Chemical Toxicology, 48, 1218-1221. 
[15] KURANCHIE-MENSAH, H., MANUKURE ATIEMO, S., MAUD, L., PALM, N., BLANKSON-ARTHUR, S., OSEI TUTU, A. eta FOSU, P. 2012. «Determination of organochlorine pesticide residue in sediment and water from the Densu river basin, Ghana». Chemosphere, 86, 286-292.

[16] DÍAZ-CRUZ, M.S. eta BARCELÓ, D. 2015. Personal care products in the aquatic environment. Springer Publishing, Nueva York.

[17] POSADA-URETA, O., OLIVARES, M., NAVARRO, P., VALLEJO, A., ZULOAGA, O. eta ETXEBARRIA, N. 2012. «Membrane assisted solvent extraction coupled to large volume injection-gas chromatography-mass spectrometry for trace analysis of synthetic musks in environmental water samples». Journal of Chromatography A, 1227, 38-47.

[18] VENTRICE, P., VENTRICE, D., RUSSO, E. eta DE SARRO, G. 2013. «Phthalates: European regulation, chemistry, pharmacokinetic and related toxicity». Environmental Toxicology and Pharmacology, 36, 88-96.

[19] CHEMSPIDER. http://www.chemspider.com (azken bisita: 2019ko ekainean).

[20] FIDALGO-USED, N., BLANCO-GONZALEZ, E. eta SANZ-MEDEL, A. 2007. «Sample handling strategies for the determination of persistent trace organic contaminants from biota samples». Analytica Chimica Acta, 590, 1-16.

[21] IPARRAGUIRRE, A., RODIL, R., QUINTANA, J.B., BIZKARGUENAGA, E., PRIETO, A., ZULOAGA, O., CELA, R. eta FERNANDEZ, L.A. 2014. «Matrix solid-phase dispersion of polybrominated diphenyl ethers and their hydroxylated and methoxylated analogues in lettuce, carrot and soil». Journal of Chromatography A, 1360, 57-65.

[22] ZIARRUSTA, H., OLIVARES, M., DELGADO, A., POSADA-URETA, O., ZULOAGA, O. eta ETXEBARRIA, N. 2015. «Multiscreening determination of organic pollutants in molluscs using matrix solid phase dispersion». Journal of Chromatography A, 1391, 18-30.

[23] BARKER, S.A. 2007. «Matrix solid phase dispersion (MSPD)». Journal of Biochemical and Biophysical Methods, 70, 151-162.

[24] VILLAVERDE-DE SAA, E., BENITO QUINTANA, J., RODIL, R., FERRERO-REFOJOS, R., RUBI, E. eta CELA, R. 2012. «Determination of perfluorinated compounds in mollusks by matrix solid-phase dispersion and liquid chromatography-tandem mass spectrometry». Analytical and Bioanalytical Chemistry, 402, 509-518.

[25] MUNOZ-ORTUNO, M., MOLINER-MARTINEZ, Y., COGOLLOSCOSTA, S., HERRAEZ-HERNANDEZ, R. eta CAMPINS-FALCO, P. 2012. «A miniaturized method for estimating di(2-ethylhexyl) phthalate in bivalves as bioindicators». Journal of Chromatography A, 1260, 169-173.

[26] WU, R.Q., ZHAO, X.F., WANG, Z.Y., ZHOU, M. eta CHEN, Q.M. 2011. «Novel molecular events in oral carcinogenesis via integrative approaches». Journal of Dental Research, 90, 561-572.

[27] GARMENDIA, L., SOTO, M., VICARIO, U., KIM, Y., CAJARAVILLE, M.P. eta MARIGOMEZ, I. 2011. «Application of a battery of biomarkers in 
mussel digestive gland to assess long-term effects of the prestige oil spill in Galicia and bay of Biscay: tissue-level biomarkers and histopathology». Journal of Environmental Monitoring, 13, 915-932.

[28] FISHER, W.S., OLIVER, L.M., WINSTEAD, J.T. eta LONG, E.R. 2000. «A survey of oysters crassostrea virginica from Tampa bay, Florida: associations of internal defense measurements with contaminant burdens». Aquatic Toxicology, 51, 115-138.

[29] COUCH, J.A. Chemically induced histopathology in aquatic invertebrates. En: Pathology of marine and estuarine organisms (pp. 359-391). 1992, CRC Press, Boca Ratón.

[30] MARIGOMEZ, I., CAJARAVILLE, M.P., ORBEA, A. eta GARMENDIA, L. 2006. «Effects of the prestige oil spill on cellular biomarkers in intertidal mussels-results of first year of studies». Marine Ecology Progress Series, 306, 177-189.

[31] IZAGIRRE, U., GARMENDIA, L., SOTO, M., ETXEBARRIA, N. eta MARIGOMEZ, I. 2014. «Health status assessment through an integrative biomarker approach in mussels of different ages with a different history of exposure to the prestige oil spill». Science of the Total Environment, 493, 65-78.

[32] POSADA-URETA, O., OLIVARES, M., ZATÓN, L., DELGADO, A., PRIETO, A., VALLEJO, A., PASCHKE, A. eta ETXEBARRIA, N. 2016. «Uptake calibration of polymer-based passive samplers for monitoring priority and emerging organic non-polar pollutants in WWTP effluents». Analytical and Bioanalytical Chemistry, 408, 3165-3175.

[33] CLAUSEN, I. eta RIISGARD, H.U. 1996. «Growth, filtration and respiration in the mussel Mytilus edulis: no evidence for physiological regulation of the filter-pump to nutritional needs». Marine Ecology Progress Series, 141, $37-45$.

[34] WU, H., SOUTHAM, A.D., HINES, A. eta VIANT, M.R. 2008. «Highthroughput tissue extraction protocol for NMR- and MS-based metabolomics». Analytical Biochemistry, 372, 204-212.

[35] VIANT, M.R. 2007. «Revealing the metabolome of animal tissues using ${ }^{1} \mathrm{H}$ nuclear magnetic resonance spectroscopy». Methods in Molecular Biology, 358, 229-246.

[36] MADISON-QINGDAO METABOLOMICS CONSORTIUM DATABASE. http://mmcd.nmrfam.wisc.edu (azken bisita: 2016ko ekainean).

[37] BIOLOGICAL MAGNETIC RESONANCE DATA BANK. http://www. bmrb.wisc.edu (azken bisita: 2016ko ekainean).

[38] THE HUMAN METABOLOME DATABASE. http://www.hmdb.ca (azken bisita: 2016ko ekainean).

[39] R.P. ELLIS, J.I. SPICER, J.J. BYRNE, U. SOMMER, M.R. VIANT, D.A. WHITE eta S. WIDDICOMBE. 2014. «1H NMR metabolomics reveals contrasting response by male and female mussels exposed to reduced seawater 
$\mathrm{pH}$, increased temperature, and a pathogen». Environmental Science \& Technology, 48, 7044-7052.

[40] VIANT, M.V., ROSENBLUM, E.S. eta TJEERDEMA, R.S. 2003. «NMRbased metabolomics: A powerful approach for characterizing the effects of environmental stressors on organism health». Environmental Science \& Technology, 37, 4982-4989.

[41] SAMUELSSON, L.M, FORLIN, L., KARLSSON, G., ADOLFSSONERICI, M. eta JOAKIM LARS-SON, D.G. 2006. «Using NMR metabolomics to identify responses of an environmental estrogen in blood plasma of fish». Aquatic Toxicology, 78, 341-349.

[42] TUFFNAIL, W., MILLS, G.A., CARY, P. eta GREENWOOD, R. 2009. «An environmental ${ }^{1} \mathrm{H}$ NMR metabolomic study of the exposure of the marine mussel Mytilus edulis to atrazine, lindane, hypoxia and starvation». Metabolomics, 5, 33-43.

[43] HINES, A., OLADIRAN, G.S., BIGNELL, J.P, STENTIFORD, G.D eta VIANT, M.R. 2007. «Direct sampling of organisms from the field and knowledge of their phenotype: key recommendations for environmental metabolomics». Environmental Science \& Technology, 41, 3375-3381. 